2002s-34

\title{
European Economic Integration and the Labour Compact, 1850-1913
}

Michael Huberman, Wayne Lewchuk

Série Scientifique

Scientific Series

CI RANO 


\section{CIRANO}

Le CIRANO est un organisme sans but lucratif constitué en vertu de la Loi des compagnies du Québec. Le financement de son infrastructure et de ses activités de recherche provient des cotisations de ses organisationsmembres, d'une subvention d'infrastructure du ministère de la Recherche, de la Science et de la Technologie, de même que des subventions et mandats obtenus par ses équipes de recherche.

CIRANO is a private non-profit organization incorporated under the Québec Companies Act. Its infrastructure and research activities are funded through fees paid by member organizations, an infrastructure grant from the Ministère de la Recherche, de la Science et de la Technologie, and grants and research mandates obtained by its research teams.

\section{Les organisations-partenaires / The Partner Organizations}

-École des Hautes Études Commerciales

-École Polytechnique de Montréal

-Université Concordia

-Université de Montréal

-Université du Québec à Montréal

-Université Laval

-Université McGill

-Ministère des Finances du Québec

-MRST

-Alcan inc.

- AXA Canada

-Banque du Canada

-Banque Laurentienne du Canada

- Banque Nationale du Canada

- Banque Royale du Canada

- Bell Canada

- Bombardier

-Bourse de Montréal

-Développement des ressources humaines Canada (DRHC)

-Fédération des caisses Desjardins du Québec

-Hydro-Québec

-Industrie Canada

-Pratt \& Whitney Canada Inc.

-Raymond Chabot Grant Thornton

-Ville de Montréal

(C) 2002 Michael Huberman et Wayne Lewchuk. Tous droits réservés. All rights reserved. Reproduction partielle permise avec citation du document source, incluant la notice (C).

Short sections may be quoted without explicit permission, if full credit, including (C) notice, is given to the source.

Les cahiers de la série scientifique (CS) visent à rendre accessibles des résultats de recherche effectuée au CIRANO afin de susciter échanges et commentaires. Ces cahiers sont écrits dans le style des publications scientifiques. Les idées et les opinions émises sont sous l'unique responsabilité des auteurs et ne représentent pas nécessairement les positions du CIRANO ou de ses partenaires.

This paper presents research carried out at CIRANO and aims at encouraging discussion and comment. The observations and viewpoints expressed are the sole responsibility of the authors. They do not necessarily represent positions of CIRANO or its partners.

\section{ISSN 1198-8177}




\title{
European Economic Integration and the Labour Compact, 1850-1913*
}

\author{
Michael Huberman ${ }^{\dagger}$ and Wayne Lewchuk ${ }^{*}$
}

\begin{abstract}
Résumé / Abstract
La mondialisation fut présente dans toute son ampleur en Europe dans la période avant 1913. Or, la croissance des échanges internationaux a suscité l'instabilité des salaires et des emplois. Face à la demande des travailleurs pour des garantis contre l'insécurité, les autorités nationales ont établi des accords de travail composés de programmes d'assurance chômage et de compensation pour les accidents de travail, ainsi que d'autres mesures fixant la journée du travail et assurant l'inspection des entreprises. Ces accords ont donné aux travailleurs un type d'assurance car ils comprimaient les structures des salaires. Dans cet article, on construit pour dix-sept pays européens un indice combinant des réglementations dans les marchés du travail et des programmes d'assurance sociale. L'indice varie positivement avec le volume des échanges internationaux. On conclut que les accords de travail ont donné une raison pour les travailleurs de supporter le libre-échange. Donc, dans les années avant 1913, la mondialisation était associée à l'intervention de l'État. Nos résultats confirment ceux de Rodrik et d'Agell pour la période après 1945.

Globalization was a fact of life in Europe before 1913, but as trade shares increased, so did wage and employment instability. Faced by growing pressure from workers, national authorities established labour compacts - a packet of labour market regulations and social insurance programs - that defended workers against the risks they faced in and outside the factory. The labour compact provided workers with insurance because it compressed wage structures. We construct an index of labour market regulations and social insurance schemes for seventeen European countries and find that the extent of the labour compact varied with the level of openness. We conclude that the labour compact gave workers reason to support free trade because it protected them from external risk. Contrary to the received view, globalization before 1913 was compatible with state intervention. Our findings are consistent with Rodrik's and Agell's for the period after 1945.
\end{abstract}

Mots-clés : globalisation, commerce international, réglementation de marché, intégration économique, État providence

Keywords: globalization, international trade, market regulation, welfare state, economic integration

\footnotetext{
* Corresponding author: Michael Huberman, Département d'histoire, Université de Montréal, Montréal, Québec H3C 3J7, Canada. Email: Michael.Huberman@umontreal.ca

† Université de Montréal, CIRANO et CRDE

‡ McMaster University
} 


\section{Introduction}

In Globalization and History, O'Rourke and Williamson (1999) claimed that the winds of integration before 1913 carried the seeds of its own destruction. Their argument is that migration from the Old to New World and the transport revolution that brought cheap grains to Europe precipitated changes in factor prices and in the distribution of income on both sides of the Atlantic. Growing inequality in the United States led to controls on immigration; falling agricultural prices in Europe resulted in the reintroduction of tariffs. By the interwar years, "globalization [had] killed itself (ibid., p. 287)." State intervention had pushed aside markets. These were the lessons of history. But were these trends inevitable? Were alternative policies available to offset growing inequality and to conserve the benefits of economic integration?

In this paper we draw other lessons from the pre 1913 years. The point of departure for O'Rourke and Williamson is the theory of factor-price equalization developed by Eli Heckscher and Bertil Ohlin to help account for Scandinavian catch-up. But twenty years earlier, another Swedish economist, Gustav Cassel, sought to understand the potential role for state policy in promoting economic growth. ${ }^{1}$ Writing at the time when the development of Swedish welfare state was in its infancy, Cassel criticised German tariff policy and Bismarckian social measures for their rigidity and argued that they were inappropriate for Sweden because of its dependence on international trade. He believed that social policy could be designed in such a way that gave workers some measure of protection, and at the same time enabled and encouraged them to take advantage of the opportunities available to Sweden because of its access to international markets.

Extending Cassel's insights, we examine the association between social policy and openness in Europe before 1913. We define social policy to include the labour compact - the packet of labour market regulations and social entitlements - national authorities established in the decades before World War I that were intended to defend workers against the risks they faced in and outside the factory. It is our contention that the extent of the labour compact varied positively with the degree of openness. An expansive labour compact gave workers reason to support free trade because it protected them from the wage and employment instability that was associated with openness or external risk. Since the compact was a viable alternative to tariff

\footnotetext{
${ }^{1}$ We thank Jonas Agell for sharing with us his knowledge of Cassel.
} 
protection, we conclude that globalization before 1913 was not inconsistent with an activist social policy.

Rodrik (1997, 1998) and Agell (1999, 2001; see also Cameron (1978), Krueger (2000)) provide theoretical support for the relation between openness and social policy. These authors have argued that in the period after 1945 increased exposure to international trade led to greater wage and employment instability, which, in turn, forced national authorities to extend their safety nets. While Rodrik stressed the relation between economic integration and the instability of labour-market outcomes, Agell emphasized the role of what he called "labour market institutions" in compressing wage structures, thereby providing workers with a degree of social insurance. Summarizing their views, Rodrik (1998, p. 1028) remarked that markets and governments are not substitutes, but that there exists a "degree of complementarity" between the two.

Our contribution to this line of reasoning is mainly empirical. For 17 European countries, we construct a Labour Compact Index that incorporates 11 elements of labour market intervention, from the date of the first factory act to the creation of unemployment insurance. We then examine the relation between openness and the LCI. The empirical correlation we find is robust because: (a) it is unaffected by the inclusion of other control variables; (b) it holds for various measures of government intervention; (c) it exists for measures of government intervention drawn from other data sets; (d) it prevails for both high and low income countries; and (e) it is not an artifact created by outliers.

The paper is organised as follows. Section 2 surveys contemporary opinions and more recent treatments of the relation between openness and social policy. There is much recent research on openness and the origins of the welfare state, but there is no attempt to draw these two phenomena together. Section 3 summarizes the intuitive reasons we would expect to see a link between openness and social policy, and we introduce other approaches to trade policy, mainly from political science, that we draw upon in our statistical analysis. In Section 4, we construct the LCI and provide a preliminary examination of the data. Section 5 is devoted to multivariate analysis of the relation between openness and social policy. A concluding section situates our findings in the larger debates on globalization. 


\section{European economic integration, standards of living and social policy}

The first great wave of global economic integration and the first steps toward the creation of the welfare state coincided in the thirty years or so before WWI, but despite their simultaneity these two phenomena are most often treated separately. In fact, economists and historians who have studied these two phenomena take somewhat opposing positions. According to one school, globalization led to improvements in European workers' standards. This view ignores the demand for social policy. But others, giving emphasis to domestic factors, have traced the origins of social policy to the deterioration of living and working conditions during the same period. This view ignores the role of globalization. In many ways, these two approaches seem to be talking past each other. ${ }^{2}$ Contemporaries thought differently. They saw that a direct link between openness and the demand for social policy. The objective of this section is survey the distinct approaches to globalization and the rise of the welfare state and to suggest ways that these two phenomena may be in fact connected.

\section{European economic integration and the demand for social reform}

Exploiting a newly constructed real wage series, O'Rourke and Williamson (O\&W) have provided new benchmark estimates of the effect of openness on standards of living and the distribution of income around the world between 1870 and 1913. ${ }^{3}$ The transport and grain revolutions that forged the integration of Old and New Worlds affected European countries unequally because of different employment and demographic structures and trade policies.

$\mathrm{O} \& \mathrm{~W}$ observed that workers in countries that remained open fared better than elsewhere. Relative to Great Britain, wage growth was particularly rapid in Scandinavia, moderate in France, Belgium and Germany, and slow in Spain and Portugal. The distribution of income also narrowed in northern Europe. This analysis gives little place to need for social policy because the market provided for everything. Government intervention in the Old World was restricted to tariff policy. ${ }^{4}$ Although tariffs may have been positively correlated with growth (O’Rourke 2000;

\footnotetext{
${ }^{2}$ There are exceptions, notably the work of political scientists. We discuss these contributions in the next section.

${ }^{3}$ The wage series is from Williamson (1995). For other contributions, see Williamson (1996), Williamson (1997), Taylor and Williamson (1997), Lindert and Williamson (2001), O'Rourke (2001). ${ }^{4}$ In discussing social spending before 1913, Lindert and Williamson (2001, p. 35) wrote that "safety nets were not yet in place."
} 
Clemens and Williamson 2001), they acted to limit real wage gains and to dampen changes in the distribution of income.

O\&W were mainly concerned with Old and New World exchanges and the resulting changes in factor prices across continents; they (O\&W 1999, p. 16) wrote that although: "[c]onvergence did take place in Europe, it was a more modest affair." But if we tilt the focus to forces promoting convergence within Europe - that went hand-in-hand with globalization - a different perspective on worker welfare emerges. Consider first the levelling effect of migration on wages. Population movements within Europe were considerable: from 1876 to 1895 about fifty percent of Italian migrants chose European destinations (Rosoli 1985; Hatton and Williamson 1998); elsewhere, Belgians travelled to France to work, and Poles to Germany. To be sure, for some countries like the Netherlands cross-border population movements were negligible, and on the whole Belgium recorded a net inflow of migrants (ibid., p. 208). For these countries as elsewhere, because trade can operate as a substitute for factor mobility, intraEuropean exchanges may have impacted on wages and working conditions in a way that challenges O\&W's rather benign view of European economic integration. ${ }^{5}$

Table 1 gives estimates of the value of exports and imports as a share of GDP for a sample of European countries. The average trade share increased by nearly twenty percent in the period, with most of the change occurring after 1900. Trade between countries with similar factor endowments and technologies dominated exchanges. In 1900, about forty percent of Belgium's trade (exports plus imports) was with France and Germany; twenty percent of Denmark's trade was with Norway and Sweden; and for Britain, trade with France, Germany and the Netherlands was about eighty percent of the value of its trade with the US and India (Mitchell 1980). Exchanges of this type made the demand for labour very responsive to changes in its price (Rodrik 1997, pp. 19-20). As continental markets became more integrated, employers and final consumers would have substituted foreign European workers for domestic workers (this has the same effect as increasing the domestic labour supply), either by investing abroad or by importing the products made abroad - and wages and working conditions for comparable groups of workers across the continent should have been driven down. The strong dependence on a select number of European trading partners meant that the continent's workers were highly

\footnotetext{
${ }^{5}$ Intra-European exchanges maintained their share in the world trading system from 1870 to 1913 (Kenwood and Lougheed 1983).
} 
susceptible to changes in commercial policy and faced uncertainty because of it. The Netherlands' trade share failed to increase over the period because its most important trading partner, Germany, had brought in tariffs. This was also the case for Switzerland. Denmark got off easier; the UK was the main destination of its exports. ${ }^{6}$

The upshot is that movements of people and goods within Europe on the one hand, and exchanges across continents on the other, may have had offsetting effects on worker welfare. The net result may have spurred workers to seek new forms of social protection. Recent research has pointed to these conflicting trends. While real wages increased rapidly in certain countries, working conditions may have not improved to the same extent. In fact, Huberman and Lewchuk (1998) found that until 1900 in Denmark and Sweden work hours remained long, between eleven and half and twelve hours per day on average. ${ }^{7}$ Huberman and Lewchuk also reported that across the continent work hours were longer than average in sectors, like textiles, which faced considerable international (i.e., European) competition. ${ }^{8}$ Other indicators give credence to the view that wage gains may not have offset the poor working conditions and the wage and employment instability of the new economic order. For Belgium, which according to O\&W saw moderate wage growth, Scholliers (1991) found only meagre improvements in family budgets and fluctuations in the price of bread was a source of great distress in the mid 1880s; Alter (1984) reported that the proportion of children at work in Belgium was the same in the early 1890s as it was at mid-century. For France and parts of Germany, new evidence on heights suggests that living standards and working conditions were not improving at any great rate (Weir 1997, Twarog 1997).

The rise of the welfare state in an open economy framework: some possible links

\footnotetext{
${ }^{6}$ In 1900, Dutch exports to Germany were nine times the value of trade with Belgium and three times that with the UK (Mitchell 1980).

${ }^{7}$ There is independent evidence of long work hours in Scandinavia. For Denmark, see UK PP 1893-94 XXXIX, Part II, p. 780; Finland, see Heikkinen (1997, pp. 152-58); Sweden, see Tegle (1982, pp. 9-20). We owe the latter reference to Lars Svennson.

${ }^{8}$ For 1870 , an excellent starting point on work hours across countries and by sectors is the British consular reports: UK PP 1870 LXVI, PP 1871 LXVIII, PP 1872 LXII. The reports were superseded by the Abstract of Foreign Labour Statistics published occasionally before the WWI and the Commission on Labour, Foreign Reports. See, PP 1899 XCII, PP 1901 LXXIII, PP 1906 CXIII, PP 1893-94 XXXIX. For 1900, the reports indicate that in Belgium the average work week was 69 hours; Italy, 67 hours;
} 
For the most part, historians of the welfare state have not made much of the connection between increased exposure to international trade and the rise in workers' demands for improved working conditions and some basic amount of insurance. Comparative histories of the rise of social policy tend to begin with Bismarck who first introduced compulsory accident and health insurance and old-age pensions in the 1880s. The UK is believed to have followed the German model after Lloyd George's visit there in 1908 (Harris 1984, Hay 1977). Like a contagion effect, other European countries adopted similar measures (Kohler et al., 1982). A different picture surfaces, however, if we broaden social policy to include both social entitlements and labour market reform - the labour compact nations provided workers.

We have assembled a data set for 17 countries in order to trace the development of social reform broadly defined and to assess its uniformity across Europe. We have divided reforms into two main groups: labour market regulations that influenced the supply of labour and regulations that affected the conditions under which work was performed (Table 2); and social insurance programs that protected workers during periods when they were unable to work (Table 3 ). ${ }^{9}$ In constructing Table 2, wherever possible we used the standards of the Final Protocol of the International Conference on Labour in Factories and Mines held in Berlin in 1890, which outlined a model labour code that was to be the basis of a late nineteenth century European social charter. ${ }^{10}$ We do not set any standards for factory inspection or the introduction of factory acts reported in the last two columns of the table. By 1913, all countries had some form of factory inspection and most countries had put in place the 12 years old standard for children's work. Women were left unprotected in more than half of our sample.

France and Germany, 65; Spain, 64; Denmark and the Netherlands, 64; UK, 54. We leave a more detailed examination of work hours for a future paper.

${ }^{9}$ Our first step was to track down when these reforms were introduced. This was not always straightforward. In some cases our sources provided contradictory information. Where these conflicts could not be resolved, we gave priority to information found in official publications; when official reports were themselves in conflict, we assumed that change occurred mid-way between the last two dates identified. Sources consulted: Factory acts, hours of labour for young workers and women, age of admission to factory work, age at which night work permitted, night work for women - Brooke (1898), Fraser (1984), IALL (1907), UK PP 1905 LXXIII, p. 81. Factory inspection - IALL (1911), ILO (1911, 1939).

${ }^{10}$ The Final Protocol recommended that children under 12 years of age not be allowed to perform factory work; that women should be not permitted to work at night; that the length of the working day for children under 14 years be set at 10 hours and that of women be limited to 11 hours. Table 2 provides the dates when national legislation embodied these values 
Table 3 gives the dates for the introduction of social insurance and accident compensation schemes. $^{11}$ Less than half of our countries had introduced some form of old age and unemployment insurance before 1913. We have not included the Poor Law in our tabulation. In Western Europe, Poor Law expenditures as a share of national product were declining from 1850 on - by 1880 they represented as little as 0.5 to 1.0 percent of GNP. ${ }^{12}$ Table 3 does not fix standards for social expenditure because of the wide variability of these measures and how they were funded. In Germany, sickness insurance coverage was compulsory with penalties falling on employers who failed to make sure their workers were covered. Workers and employers shared the payment premiums. Denmark had a voluntary system, with high levels of government subsidies and relatively widespread participation. Belgium's voluntary system lay at the other extreme; it was actuarially unsound and with little government subsidy, membership stagnated relative to the other funds. The French system fell somewhere in between in terms of subsidy and membership ${ }^{13}$ Unemployment insurance was equally varied. In all countries, coverage was limited to selected groups of workers, and only in the UK was it compulsory.

Tables 2 and 3 suggest divergence as opposed to convergence in the spread of the labour compact. The UK and France sought to regulate factory conditions and limit the work time of women and children; the northern European countries favoured social entitlements. Germany seems to be the exception and not the rule. It introduced some social entitlements - excluding unemployment insurance - at early date, and its regulation of factory conditions was lax compared to the UK and France. How have historians explained these variations? Their focus has been on domestic factors only, including but not restricted to the extension of the franchise, levels of unionisation, and the demographic and occupational distribution of populations. Lindert (1994) provided the most comprehensive analysis of the determinants of social spending on unemployment relief, old age pensions, health care and housing. Using an international data set covering the period 1880 to 1930 , he found that the percentage of the adult population eligible

\footnotetext{
${ }^{11}$ Sources consulted: Old age pensions, sickness insurance, unemployment insurance - Ambrosius and Hubbard (1989) Association Internationale (1913), Blaustein and Craig (1977), Fraser (1984), Rimlinger (1971). Accident compensation - Ambrosius and Hubbard (1989), Bellom (1897), Droz (1889), Villard (1913), US Department of Labor $(1911,1914)$.

${ }^{12}$ This trend reflected, according to Lindert (1998), the shift in the balance of political power from labour-hiring rural landlords to urban employers who wished to reduce their tax burden.

${ }^{13}$ Murray (2000) reviews these different schemes.
} 
to vote, Protestantism, and an ageing population were determinants of spending, while income levels and the level of development were poor indicators.

Lindert's own research suggests that other factors may have also been at work. Without the exception of age, Lindert does not specify the changes in the risk environment faced by workers. $^{14}$ One possible change in the risk environment for many workers, as Table 1 demonstrates, was increased exposure to international trade. As for the differences in programs between countries, it would be difficult to attribute these variations solely to the extent of the male franchise which by 1913 was roughly similar for northern and western European countries. $^{15}$ Indeed, the UK which had perhaps the most extensive labour compact also had a relatively low proportion of adult males eligible to vote. We speculate that the observed pattern of social protection was the result of different degrees of openness. The northern European countries may have offered more social entitlements because they were more open.

There were other ways that political representation may have mattered for the relation between openness and social policy. While Germany had granted universal male suffrage, it would be difficult to call it a democracy because its executive power was independent of the legislative assembly. Lindert does correct for this. But along with the extension of the franchise, certain European states introduced new systems of representation, most famously electoral systems based on proportional representation. ${ }^{16}$ Political scientists like Rogowski (1987) have observed the correlation between proportional representation and trade shares. ${ }^{17}$ But we also know that this type of electoral system permits workers and other large constituencies who may not be members of the ruling party to have their voices heard. Thus, in an open economy, social reform may be as much related as to the type of representation as the extension of the franchise. We explore this possibility further below.

\footnotetext{
${ }^{14}$ As Lindert noted, the positive effect of an ageing adult population on social transfers may simply have reflected increased out-migration in the period before the War.

${ }^{15}$ The percentage of the adult male population eligible to vote in 1913 was Belgium, 91.6; Denmark, 87.5; Finland, 88.5; France, 90.5; Germany, 91.1; Italy, 89.8; Netherlands, 67.0; Norway, 70.1; Sweden, 76.4; Switzerland, 76.4; UK, 62.4. Sources: see Appendix.

${ }^{16}$ The countries and dates of the introduction of proportional representation are found in the Appendix.

${ }^{17}$ The point here is not that countries chose PR to increase their trade shares, but that the introduction of PR has the consequence of increasing trade. The introduction of PR in Belgium was the result of political negotiation between Catholic and Liberal parties; it had the result of keeping Belgium open to trade, because workers could participate in policy formation. We discuss this further below
} 
Contemporary insights into the relation between openness and social reform

For contemporaries globalization was a fact of life. Consider the case of Belgian workers who around the time of the social upheavals of the 1880s established boulangeries socialistes, bread co-operatives, that tied their welfare directly to imports of American wheat (Witte and Craeybeckx 1987, p. 109). The co-operatives they founded were intended to stabilize expenditures on bread, clearly a large part in workers' household budgets (Scholliers 1991). Although they actively encouraged trade, leaders of the co-operative movement and the Parti ouvrier belge, recognized that working class institutions offered only partial and incomplete insurance against the risk of increased international exposure (Leboutte et. al. 1998). In the case of the textile industry, Belgian work hours were the longest in Europe and reformers linked poor working conditions to international competition. Despite the widespread belief that long hours were unhealthy, individual firms could not be counted on to reduce collectively the length of the workday. ${ }^{18}$ Workers could not negotiate these conditions themselves; state intervention, they argued, was their best recourse. But the degree of Belgian international exposure - it was the greatest in Europe in 1913 - also affected the nature of workers' demands. Alongside restrictions on work hours, there was a push for unemployment insurance to support workers faced with the prospects of job loss due to changes in foreign markets. In the end, the Parti ouvrier belge backed free trade (Bairoch 1989), because it was able to use its support for trade to gain a larger influence in designing social protection (Kossmann 1978). ${ }^{19}$

Like workers, late nineteenth century employers recognized the connection between openness, the standard of living and the demand for social reform, but in their eyes the three dimensions represented a type of 'trilemma'. Rising wages and access to international market went together; and along another dimension, reform in a closed economy was also possible. But in an open economy, wage gains and reform were irreconcilable. If employers could not offload their contributions to social entitlements and other programs, the labour compact would lead to a loss of competitive advantage, a balance of payments crisis and inevitably to downward pressure on wages.

\footnotetext{
${ }^{18}$ This argument was common among European reformers (Rist 1898) into the interwar period. Hicks (1963) gave their arguments theoretical support in his classic study.

${ }^{19}$ Trade unions and social democrats in Germany, Italy and the U.K, Italy supported free trade (O'Rourke 1997). The German case is interesting because it points to the fact that workers were less than satisfied with Bismarck's social policy which was seen as a complement of his tariff policy.
} 
National authorities had to balance employers' concerns against workers' demands for reform. One option they tried was the creation of a wider European social union that fixed standards for working conditions across the continent. The alternative, they feared, was a race to the bottom, that is to the lowest standards of social insurance and factory regulation prevailing in Europe. The Swiss and then the Germans spearheaded the early movements to set international standards, but at the Berlin conference of 1890, even the developed countries could not find common ground (Rolin-Jaequemyns 1890). There was only agreement on the content of phosphorous in matches. ${ }^{20}$ After 1890, it was left to unofficial and independent organizations of reformers and workers, often at an industry level, to exert pressure on national authorities in order to avoid the inevitable 'race to the bottom'. Although multilateral agreements were difficult to negotiate, states did sign bilateral arrangements. In 1904, France, concerned about the guarantees it had made to its workers owing to an influx of Italian migrants, sought to establish a labour treaty with its neighbour. It gave Italian workers in the hexagon the same level of benefits that French workers received, and in exchange the Italian government introduced in the peninsula some measures of the more advanced French labour legislation (Follows, p. 170).

In sum, despite their simultaneity, the rise of social policy and the trend toward international market integration have been treated as distinct developments. Historians have analysed the rise of the welfare state in a closed economy framework; economic historians of globalization have tended to see tariff policy as the sole option available to governments. Contemporaries believed otherwise. Workers demanded that openness be met with social policy. Faced by the failure of international accords, national authorities had to devise policies that reconciled the interests of workers and employers. Where this was achieved, to what extent and how is the subject of the remainder of this paper.

\section{The labour compact and openness: some formal hypotheses}

There are two aspects to the link between openness and social policy. The first is the relation between the demand for social protection and exposure to trade and, second, the role of the labour compact, broadly defined, in providing this protection.

\footnotetext{
${ }^{20}$ Yet, according to Follows (1952), Berlin did influence the Danish and Austrian governments' decision to forbid Sunday work.
} 
Rodrik $(1997,1998)$ treats the first aspect. His starting point is the observation that the current debate about globalization has tended to focus on North-South flows, giving less attention to exchanges among countries with similar factor endowments. But in the period after 1945 - as was the case in the period before 1913 - trade between countries that look alike has remained important. These type of exchanges have the effect of flattening labour demand curves and lead to a greater instability of labour-market outcomes. "Shocks in labor demand - caused, for instance, by a sudden increase or decrease in labor productivity - result in much greater volatility in both earnings and hours worked (Rodrik 1997, pp. 19-20)." Increased volatility gave rise after 1945 to the demand for a safety net, or what Rodrik called "government consumption," to smooth income flows.

Agell $(1999,2001)$ defines labour market institutions broadly to include the provision of social insurance and labour regulations like minimum wage and factory legislation that affect the supply and demand for labour. These institutions act as an insurance mechanism because they tend to compress wage structures. In the absence of perfect capital markets, the representative worker is willing to exchange a lower expected wage for a wage structure that offers insurance against uncertainty concerning "who-one-will-be in the wage distribution (Agell 2001)." Unions through collective bargaining can negotiate this type of protection, but Agell shows that government intervention is preferred because it can deliver the same amount of protection with smaller amounts of unemployment. ${ }^{21}$

Social protection can take many forms. Social entitlements give workers direct support against the vicissitudes of trade. Labour market regulations also provide insurance. In the context of the nineteenth century, laws restricting the labour supply of women and children and limiting the length of the workday raised the wages of unskilled male workers relative to average wages. Compressed wage structures assured male workers that there was some minimum level below which their standards of living would not fall. Factory regulation also provided insurance because it was universal. Before national authorities intervened, the provision of above average working conditions was restricted to paternalist employers who were scattered over the countryside and industrial regions. National regulations gave workers assurance that their 'rights' to these conditions were transferable, and hence their income opportunities and mobility

\footnotetext{
${ }^{21}$ The point here is that unions' interference with relative factor prices results in greater levels of unemployment than what is produced by redistributive government policy.
} 
increased. Notwithstanding these features, even modest amounts of government intervention have redistributive effects and reduce the variance of living standards. Sinn (1995) argued that, like the provision of public goods, the entire system of redistributive taxation involves some element of risk sharing and social insurance. Thus even nineteenth-century factory inspection provided for income smoothing because it was paid by taxes that deviated from the benefit taxation criterion and made the rich the net contributors and the poor the net receivers of economic resources. ${ }^{22}$

Holding levels of openness constant, not all national authorities are likely to react equally and provide the same degree or type of social protection. Economists (Alesina et. al. 1999) analyzing the determinants of growth have observed that more polarized countries tend to invest less in public goods, like schools. ${ }^{23}$ To Katzenstein (1985, p. 29; see also, Gourevitch 1986), country or population size as opposed to its linguistic or ethnic fragmentation is the primary determinant of government spending. In historical context, small European states were best suited to provide social protection, because of their "economic flexibility and political stability (Katzenstein 1985, p. 26).” Small states promoted democratic corporatism and its institutions including labour market institutions - furnished them with an infrastructure to weather the "open and vulnerable" nature of their economies.

Many of the small European states also have forms of proportional representation (PR) whose origins we have noted can be traced to the years before and immediately after WWI. For the period after 1945, Rogowski (1987; see also Mansfield and Busch 1995) proposed that it is political institutions and not size that matters in the relation between openness and social policy. Polities with PR are most likely to support openness because representatives of large electoral districts are more insulated from regional and sectoral pressure. After reviewing a number of key episodes - and contrary to the received wisdom - Rogowski found that in PR systems political parties tend to be "more disciplined, more coherent and more ideological" and more secure against sudden shifts in voter sentiments. ${ }^{24}$ PR builds trust among political parties of various

\footnotetext{
${ }^{22}$ For most of the countries in our data set, public finances before 1913 conformed to the model of redistributive taxation, even in the UK, France and Germany (Schremmer 1989).

${ }^{23}$ The idea here is that it is difficult to agree on public expenditures in fragmented societies.

${ }^{24}$ Rogowski (1987, p. 200) summarised the main idea: "When automakers or dairy farmers entirely dominate twenty small constituencies and a powerful minority in fifty more, their voice will be heard in a nation's councils. When they constitute but one or two percent of an enormous district's electorate,
} 
stripes. $^{25}$ Excluding extremist parties, various combinations of political parties can combine at any time in setting the policy agenda. This entails that parties need to demonstrate their honesty in negotiations which is manifested in their willingness to cooperate. Where workers participate in PR they can form coalitions with liberal or centrist parties that support free trade. Because of the long-run stability of PR, workers in these circumstances can exchange their conditional support of trade for improved social protection.

These insights from economics and political science suggest a number of hypotheses that we will draw upon to study the link between globalization and the labour compact before 1913 . $^{26}$

1) For all countries it is expected that government intervention increased with the degree and risk of openness. This correlation should be robust across income levels and hold for different measures of labour market intervention. The type of intervention would have varied. Where degrees of openness were greater, we would expect to see more direct forms of protection. Labour market regulations would be more prevalent in countries where the extent of openness was smaller. We can also test the ancillary hypothesis that social policy, because it stabilized wages and employment, was an alternative to tariff protection. If the labour compact varied with openness, and because tariff protection moved inversely with trade, we would expect to find a negative relation between the labour compact and tariffs.

2) At a given level of openness, the level and nature of protection would have varied with social and political factors. Population size and its fragmentation would be negatively correlated with government intervention. Katzenstein believed that the distinction between small and large countries took shape in the tumult of the inter-war years. But many of the institutional and historical conditions that he thought relevant for the 1920s were well in place in the years before

representatives may defy them more freely...The smaller the size of each constituency, the more homogeneous is each district, the fewer is the number of special interests that are likely to exist per constituency, and the greater will be the political influence of each pressure group in that district. Small electoral districts encourage patronage and pork-barrel politics... [and] yield trade policy that covers more types of goods and services than would be the case in a country characterized by large electoral districts and less influential interest groups." Large constituencies make PR more exact.

${ }^{25}$ We benefited from discussions with Peter Katzenstein and Bo Rothstein on this point.

${ }^{26}$ In this paper we limit ourselves to the relation between openness and labour market institutions. We do not look at the ancillary hypothesis that labour market institutions compressed wage structures. In passing, we note that there is some support for this hypothesis. For the Netherlands, Smits and van Zanden (1998) observed that in the period before 1913, the gap between skilled and unskilled wages closed. Heikkinen (1997) reported a similar finding for Finland. O\&W's evidence on the narrowing of 
1913. Does the relation between small economies and labour market institutions hold for the early period?

3) Most European countries had expanded the male franchise by 1913. In certain histories, the rise in percentage of eligible voters was a sufficient condition for the expansion of the welfare state. But not all states were alike in their political representation. Taking our lead from Rogowski, we consider whether workers in PR systems could use their newly won political clout to gain larger safety nets.

\section{The Labour Compact Index: preliminary analysis}

Our data set is composed of published and unpublished sources. The Appendix gives the published sources for the macroeconomic, social, political, demographic and geographic variables in the data set. ${ }^{27}$ Wherever possible we have used the most widely available sources ${ }^{28}$ The Labour Compact Index posed a different set of problems. Lindert (1994) provides estimates of social expenditure for a sample of European countries for 1880 to 1930. As a share of national product, these expenditures were small; Denmark was the most munificent country in Europe, spending 1.75 per cent of its national product on social transfers. These figures underestimate the degree of intervention in the labour market before 1913. Following Agell, labour market legislation enforcing who could work and when also provided workers with some degree of insurance.

\section{Building the Labour Compact Index}

Our first step was to combine information we had on the origins and nature of labour market reforms to allow for comparisons with the trade share across time and space. We

income distribution in those continental countries that remained open is also consistent with the hypothesis advanced here that state intervention in the labour market increased in response to openness.

${ }^{27}$ The ethnic variable is the most worrisome. Because of data availability, we were forced to use figures on 'ethonlinguistic fractionalization' for 1960. This data series is frequently used in studies of growth after 1945. Its applicability to the period before 1913 may be dubious. The assumption here is that the language mix of particular countries in our data set did not change much or that all countries changed uniformly. Consider Belgium whose linguistic divisions were about the same in 1913 as 1960; or the UK and France where a considerable portion of migrants after 1945 came respectively from Commonwealth and North African countries speaking English and French. Having said that, in statistical analysis the ethnic variable was not significant. 
summarise the data in a Labour Compact Index (LCI) found in Table 4. The LCI exploits the same methodology underlying the United Nation's Human Development Index. ${ }^{29}$ Each country's LCI is a composite of the 11 equally weighted labour market regulations and social insurance entitlements. For continuous variables in the LCI, benchmark minimums and maximums were defined. The minimum represented standards of working conditions and social entitlements around 1830. The maximum represented conditions found in 1913 under the most progressive legislation or those set by the 1890 Berlin Conference on Labour. Admittedly the choice of endpoints is arbitrary (thus an argument could be made that the minimum age of child workers was actually below eight years). Having said that, this approach allow us to establish the distance countries had travelled from a state of unregulated working conditions to the creation of a national labour compact. For discrete variables, such as the adoption of factory legislation, 1 signifies the regulation was in place; 0 not in place. No judgement was made on the effectiveness of factory inspection or on coverage. Thus Britain is given a value of 1 in 1840 for its factory act of 1833 , even though it covered only children in textiles. With regard to social entitlements, no attempt was made to give precise monetary values to national programs; 0 signifies the program was not in place, and 1 represensts the maximum. We say more about our valuation of these programs below.

\section{MINIMUMS MAXIMUMS}

\section{LABOR MARKET REGULATIONS}

\section{AND WORK CONDITIONS}

1) Minimum age children allowed

to work in manufacturing establishments

2) Maximum length of working day of young workers

3) Age at which night work allowed $8 \quad 18$

4) Women excluded from night work $0 \quad 1$

5) Length of working day for women

\footnotetext{
${ }^{28}$ Peter Lindert graciously provided us with his international data set on education and social spending. Wherever possible, we checked our figures against Lindert's.

${ }^{29}$ Crafts (1997) gives a description of the methodology.
} 
6) Factory Act adopted

7) Factory inspection in place

\section{SOCIAL INSURANCE ENTITLEMENTS}

8) Accident Compensation

9) Unemployment Insurance

10) Sickness Insurance

11) Old Age Insurance
0

0
1

1

We then calculated an index measuring in percentage terms the progress each country had made between the minimum and the maximum. The Appendix gives values for the continuous variables in the key years we used in our calculations. To illustrate, in 1837 the Swiss established 16 as the minimum age for children to work at night. Using the minimum and maximum values we established, the Swiss earned a score of $(16-8) /(18-8)=0.8$ for this component in $1840 . .^{30}$

In calculating the indexes for the provision of entitlements, we assigned a value of 0.5 where authorities introduced partial and/or voluntary plans for sick, unemployment and pension benefits, and accident compensation, as a precursor to more comprehensive entitlements was assigned. A number of countries increased employer liabilities in the case of accidents before introducing state administered compensation schemes. These intermediate plans were also valued at 0.5. Some examples will help here: Despite its limited coverage, the British compulsory unemployment insurance plan of 1911 was given a value of 1 , because contemporaries believed that it was the most comprehensive and generous system in Europe (Harris 1984, p. 203). The story in France is more complicated. Unemployment relief was a patchwork of private, religious and local charity, with financial aid from the communes, departments and the state; it got a index value of $0.5((0.5-0) /(1-0))$ for this social entitlement in 1913. France had put in place in 1910 a compulsory pension scheme for workers earning below a certain amount: (its original scheme of 1900 was voluntary). Despite its weakness, it covered

\footnotetext{
${ }^{30}$ This meant that we dropped the standards underlying Table 2.
} 
only three and half million workers in 1913 (Kemp 1989, p. 737), France received a score of 1 for old age pensions in that year.

Table 4 indicates that the introduction of the labour compact was uneven. In 1830 only two countries, Switzerland and Austria, had any type of regulation in place. By 1850 France, Germany, Hungary and the UK had joined them. Thereafter, the UK took the leadership. The period from 1850 to 1870 saw little change in terms of the number of countries regulating their labour markets and the extent of regulation in each country. Switzerland initiated the next wave of regulation in the 1870s; the mantle of change passed to Germany which by 1890 had the most comprehensive body of labour market regulations and social insurance entitlements. The UK did not match these improvements and by 1900 ranked only third. The extension of the labour compact was rapid in Scandinavia after 1890, and by 1900, Denmark, Norway and Sweden provided more expansive labour market protection than did Belgium. The latter did catch up in the period after 1900. For all of Europe, our measures of convergence (bottom panel of Table 4) suggest that some uniformity in the regulatory environment occurred only at the end of the period. Between 1830 and 1900 the gap between the most and least regulated nation grew and the interquartile spread increased as well; the coefficient of variation only began falling towards the end of the century.

There was variation across the type of insurance. Table 5 decomposes the LCI into two sub-components: a labour regulation index (LRI, categories 1 to 7 above) and a social insurance index (SII, categories 8 to 11$){ }^{31}$ In terms of labour regulations, Switzerland was the leader in 1913; the UK's position steadily eroded over the years; that of France improved; while Germany's was stable. While the northern European countries had relatively poor labour market regulations, their social insurance systems were more advanced. This was clearly the case for Belgium, Denmark and the Netherlands, whose systems of social entitlements were as good as anywhere else. Was this a difference between small and large, PR versus parliamentary systems, or open versus closed?

\footnotetext{
${ }^{31}$ To construct the sub-indexes in Table 5, we follow the same procedures as for the LCI in Table 4.
} 


\section{Preliminary analysis of the LCI and its components}

To fix ideas, consider again the histories of social reform in Britain and Germany on the one hand, and the smaller northern European states on the other. Inspired by liberalism, the UK was anxious to provide a framework for stable labour markets, but was reluctant to restrict the right of individuals to enter into contracts. Starting in the 1830s and 1840s, individuals were given new rights to protect themselves through collective bargaining; those deemed unable to defend their self-interest, including women and children, were offered special protection (Low 1907, Ogus 1982). The adult male worker was expected to fend for himself and to make his own provision for unemployment, old age and accident insurance. The UK moved earlier than almost any other European nation to regulate the employment of women and children, but during the 1870s and 1880s British officials rejected the Swiss proposal to set limits to the working day for men across Europe. The UK was also slow to adopt advances in social insurance pioneered elsewhere in the 1880s. In 1897 the replacement of accident compensation by a compulsory insurance scheme marked the first meaningful regulation that infringed on the rights of male adults to make their own deals with their employers.

German protective legislation was shaped in the course of a political struggle that pitted the conservative land-owning class against the most powerful socialist party in Europe. ${ }^{32}$ In an attempt to find middle ground and to consolidate the power of the state, Bismarck introduced a series of labour market regulations and social insurance programs whose evolution was almost the mirror image of that found in the UK. In the 1880s, Bismarck focused on social insurance schemes because he saw them as the most effective way to build and maintain the loyalty of the working class to the monarchy. Bismarck believed that legislation regulating working hours and work conditions would only increase the visibility of trade unions. Germany would only move towards labour market regulations in the last decade of the century as labour strife and socialist agitation continued to challenge the existing government. In 1890, Wilhelm II, prompted by a major strike in the coal mining regions the previous year, announced a 'new course' that included comprehensive labour market regulations on the British model, a half century after they became the norm in the UK.

\footnotetext{
${ }^{32}$ This paragraph is based on Canning (1996), Machlan (1985), Rimlinger (1971), and Zollner (1982).
} 
By 1913, the UK and Germany had converged, despite their different trajectories over most of the previous century. Still, throughout the period, they did share a strong predisposition to limit the use of tax revenues for pay for reform. In Bismarckian social policy, outside of old age pensions, the state's contributions were minimal. True to his Junker origins and small employer background (Rimlinger, 1971 p. 116), Bismarck was reluctant to use state funds, an inclination that underlay his decision not to introduce unemployment insurance at an early date. Accident compensation was run by the state as an insurance system rather than an assistance program (ibid., p. 117). In the UK, there was also a strong movement to limit the redistribution of resources (Lindert 1998). In the period leading up to the introduction of unemployment insurance, the degree of the central authority's contribution was a source of much debate. The Conservatives criticized a tripartite system, and in the end the Liberals agreed to limit the state's contributions to one-third of the total of employers' and workers' shares (Fraser, 1973, p. 161; Hay 1977, p. 59). With regard to the actual burden of the insurance schemes, we cannot say with any certainty whether labour demand was less elastic than labour supply, but it was the strong belief that employers in both countries - in Germany this was facilitated by tariffs - could pass on price increases to consumers in their large domestic markets. ${ }^{33}$

The situation was different in small, northern European countries. Because of their greater exposure to international exchanges (see Table 1), firms did not have the margin of manoeuvre found in larger countries. National authorities recognised that labour market regulations would raise costs in the export sector. Instead, these countries opted for social insurance schemes that were paid out of general tax revenue. In Denmark, the state actively participated in subsidizing trade union sponsored unemployment insurance initiatives. Employers did not contribute to the system until 1921 (Blaustein 1993). As elsewhere in northern Europe, the Danish plan was voluntary. Still, as one commentator wrote: "it is probably true to describe the Danish system as the most comprehensive attempt [in Europe] to bring unorganized workers into a primary voluntary plan (Wolfenden 1934, p. 34)." In Sweden state financing of a voluntary program was in place by 1914 (Clark 1941). In Belgium and the Netherlands, in contrast, national initiatives were slower to take hold and municipalities retained financial responsibility.

${ }^{33}$ See Beveridge's statements on wage offsetting cited in Harris (1984, p. 311) and Hay (1977, p. 59). 
The division between the Low Countries and Scandinavia meshes with the view that political fragmentation was a factor in the development of social spending. Scandinavia was celebrated, to borrow a phrase from Kindleberger (1951), for its "group behavior." Gourevitch (1985, p. 112; see also Rogowski 1989, p. 17; Rustow 1955) attributed Swedish collaboration to the nature of its industrial and social development. Based on their initial coalition in support of free trade, groups of farmers, commercial and financial interests, industrialists and workers coalesced around issues of social reform. Elsewhere, the Danish and Norwegian co-operative movements were among the strongest in Europe (Kindleberger 1951). In these states, state redistributive policy was an easier sell than in the Low Countries, as well as in Britain, France and Germany.

Table 6 presents a preliminary analysis of these issues. We are primarily interested in the relation between LCI and trade, but we also include the (Pearson) correlation coefficients for the other continuous independent variables in our data set. For all variables the values in this exercise are for 1870, 1900 and 1913. ${ }^{34}$ Consider, first, the trade variable. As expected, it is inversely related to tariffs, area and population. Small countries needed to trade, while larger countries (measured by area) had higher tariffs. As for the labour compact, there were differences among the LCI and its two sub-components, labour market regulation, LRI, and social insurance, SII, indexes. Consistent with Rodrik and Agell, the LCI and SII are positively related to the trade share; however the relation between LRI and trade, while positive is not significant. Those countries that opted for labour market regulations seem to have done so because of political factors; this is the standard story of the rise of the welfare state. Size (area and population) did not have much affect on the delivery of social insurance either, but note that the negative coefficient for SII-AREA is five times as large as that for LRI-AREA. This gives only small comfort to the Katzenstein hypothesis for the period before 1913. Finally, SII is negatively correlated with tariffs. Social insurance was an effective substitute for tariff policy. Open economies needed to support their workers - they could have turned to tariffs or they could have provided a safety net. In the next section, we test whether these relations hold when we control for other variables.

\footnotetext{
${ }^{34}$ We use values for 1870, 1900 and 1913 because of data limitations for some of our variables and because the average country in our sample had only reached less than 10 per cent of the Berlin and other best practice standards before 1870 .
} 


\section{The LCI and trade: another look}

Our objective in this section is to expand on the relation between the labour compact and openness, taking into account macroeconomic, social, political and geographic variables. We first examine the association between the LCI and trade, and then examine the relation between the sub-components of the index (LRI and SII) and trade. ${ }^{35}$ Finally, we turn our attention to the effect of political institutions on this relation. In all stages in our argument, we rely on tobit regressions. Our dependent variables, LCI, LRI and SII combine zero and continuous values. For this type of 'censored' data, which Greene (2000; see also Wooldridge 2000) compares to count data, tobit estimation is an appropriate procedure. ${ }^{36}$ Unless indicated otherwise, we use values for 1870,1900 and $1913 .^{37}$

\section{Trade and other influences on the labour compact}

Columns 1-5 of Table 7 give the results of regressing LCI on trade and other independent variables. Because of the possible endogeneity between LCI and trade, in the sense that greater government expenditures raise income and hence imports, we have lagged the trade variable by 10 years. We report the regression coefficients and the (absolute) ' $t$ ' values in parentheses; for the trade value we also report the 'slopes' or marginal effects in square brackets. Our baseline regression, column 1, is our story. The coefficient on the lnTRADE variable translates into an elasticity of 0.73 , evaluated at the sample mean of LCI. This equates to an increase in the index

\footnotetext{
${ }^{35}$ In his empirical work, Rodrik used two measures of risk caused by openness, the degree of openness (the trade share), and openness multiplied by standard deviation of the terms of trade. Because of data limitations, we will use the former measure. Williamson (2000) has assembled the most comprehensive data set on terms of trade before 1913. For Europe, he reported that the terms of trade were declining almost everywhere, which implies that holding the trade share constant European countries were facing the same change in risk.

${ }^{36}$ One problem is that our dependent variable is bounded between 0 and 1 . However, we have only one value in our data set equal to 1 (the SII value for the UK in 1913). When we drop the UK form our data set, the resulting estimates do not change. As a check on our procedures, we multiplied the LCI by a scalar (we chose the log odds correction); this meant giving small values to the $0 \mathrm{~s}$ in the index. We then used OLS to estimate the relation between the new values for LCI and the independent variables. Again, our main result that there is positive relation between LCI and trade was confirmed. We preferred the tobit method because of the arbitrary nature of assigning small values. We benefited from discussion with Éric Renault on selecting the appropriate estimation strategy.

${ }^{37} \mathrm{~N}=48$. We have combined Austria and Hungary because of data limitations.
} 
of 0.03, again at the mean value of LCI. ${ }^{38}$ A visual representation of the positive and significant relation between the LCI and trade is found in Figure 1. (This is an OLS estimation - there are no 0 values for LCI in 1913).

All regressions control for population. This captures the Katzenstein hypothesis, but it is also possible that the relation between the LCI and trade would be spurious without its inclusion or that of country area (Rodrik 1998). Assume that the provision of public services is subject to significant indivisibilities. Every country requires a Ministry of Labour. Then government social expenditure would be negatively correlated with country size, but since openness is negatively correlated with country size as well, the observed link in column 1 between LCI and trade could be spurious and could be due to an omitted variable. That said, we do not find this. Population and area enter with a significant and positive signs in columns 1-3.

From regression 2 on we have included time dummies for 1900 and 1913. They are significant in columns 2-4, suggesting the effects of omitted variables. In subsequent regressions we try to uncover these factors. Regression 3 includes political, social and income variables. Obviously trade can affect income. We have experimented with a number of alternatives to control for this problem. We have lagged income 10 years and we have also included the average rate of growth of income in the ten years before the date of the corresponding LCI value. The lagged income variable in column 3 is an instrumental variable. ${ }^{39}$ In all regressions neither income nor its growth rate was significant. Lindert found a similar result in his analysis of social spending. As in Lindert's study, the percentage of the adult male population eligible to vote is significant, and although the linguistic fragmentation coefficient is negative as expected it is not significant. ${ }^{40}$ Regression 5 provides a check on the robustness of our estimates and examines the relation between LCI and trade for only poor countries, that is the bottom half of our sample. ${ }^{41}$ Note that the time variables do not show up as significant here. Something is going on in rich countries that we have yet to explain.

\footnotetext{
${ }^{38}$ To calculate marginal effects, estimated coefficients in tobit regressions need to be corrected with an adjustment factor. We follow Woolridge (2000, pp. 551-57).

${ }^{39}$ The instruments were: lagged income, non-agricultural share of the labour force and all the other independent variables in Table 7.

${ }^{40}$ We have experimented with including the non-agricultural labour force and the union density rate as exogenous variables. The former presented us with problems of multicollinearity; the latter was insignificant.
} 
Some clues as to what may be happening can be found in column 6 which uses Lindert's social spending estimates (measured as a percent of national income) as the dependent variable. The trade variable is significant which sits well with our basic line of reasoning; and its elasticity, calculated at the mean value of social spending, has a value of 0.83 . Lindert's finding of a relation between democracy and spending is also confirmed. The time variables are not important and, again in contrast with our previous results, the population variable is negative and significant. Our reading of these results is that, holding constant the level of openness, small countries do seem to spend more on social spending and this predisposition is stable over time. This meshes with the Katzenstein hypothesis. The last column in the table asks whether extending the labour compact was an alternative to tariff policy. Our answer is affirmative. The coefficient on tariffs means that a reduction in protection by 10 per cent was the equivalent of a 1.5 per cent increase in the LCI. $^{42}$

\section{Trade and other influences on labour regulation and social insurance}

The relation between trade and the labour compact holds equally for the sub-components of the LCI (columns 1 and 3 of Table 8). There are differences in some of the other influences, however. The extent of the male franchise is not a significant determinant of labour market regulation. All countries, even Bulgaria, Russia and Spain, introduced some minimal standards of regulation. This is the contagion effect in the standard histories of the rise of the welfare state. As for social insurance, the time dummies and the population coefficients are not significant, results that closely mimic those of regression 6 (Lindert) in Table 7. All told, the effect of trade was greater on social insurance than on labour market regulation. The calculated elasticity of the trade variable (0.57) for column 5 is almost twice as large as that of the corresponding value for column 2 (0.33), when both are measured at the mean values. The relation between tariffs and the labour compact also shows up for its sub-components, and the tradeoff between protection and social insurance is greater than that between protection and labour market regulation.

\footnotetext{
${ }^{41}$ We have performed other checks: in one set of regressions we excluded the UK; in another we looked at rich countries only. The results are similar to those reported in column 3 of Table 7.

${ }^{42}$ After adjustment, the slope of InTARIFF is -0.058 . Evaluated at the mean level of LCI, the elasticity is 0.148 . We do not make any conjecture on the relation between tariffs and growth. These issues are better dealt with in Clemens and Williamson (2001) who use a much larger data set.
} 


\section{Trade, the labour compact and political institutions}

Recall that Rogowski hypothesized that PR systems are, contrary to expectations, more stable and that they provide an institutional framework for worker participation in decision making. ${ }^{43}$ Workers' parties can use their support for free trade as leverage to meet their goal of more expansive social protection. In Table 9 we test for this proposition. Our baseline regression is reported in column $1{ }^{44}$ Holding constant the trade share, PR is a significant factor in explaining the extent of the labour compact; we have calculated a marginal effect of a change from no PR to PR of $0.284 .{ }^{45}$ PR was mainly introduced in Europe after 1900 and it may represent one of the omitted variables we noted above. The inclusion of PR in regression 2 is in some sense a substitute for the time dummy for 1913 we reported in Tables 5 and 6 . There may be an identification problem here because the PR states in our sample were all 'small countries'. Still, not all small countries had PR systems by WWI. ${ }^{46}$ We looked next at the relation between the extension of the franchise and PR. VOTE in column 3 is significant at the 10 per cent level, its importance being overwhelmed by the interaction of VOTE and PR. For a given levels of male franchise and trade, there was a different and positive dynamic in the relation between the labour compact and PR regimes. When we examined this relation for the sub-indexes, this relation held up for social insurance but not for labour market regulation. The latter regression (4) performs poorly. The suffrage rate is not important; note as well that the trade variable is significant only at the 10 per cent level.

Belgium's experience appears to conform to these findings. ${ }^{47}$ The country saw rapid economic growth and its trade share rose, but late into the century it had few measures of social protection, and despite sizeable wage increases, work hours remained very long. It was very hard

\footnotetext{
${ }^{43}$ Recall, as well, that Rogowski found that after 1945 countries having assemblies or parliaments with large constituencies (fewer representatives) had greater trade shares. Using data from Mackie and Rose (1974), we did not find that this relation held for our period. There was a connection between trade and PR, however.

${ }^{44}$ We have included the Netherlands as a PR country. It went to PR in 1917 but, looking over its shoulder at the Belgium experience, it was well on the way to introduce it before the War (Kossmann 1978).

${ }^{45}$ This amounted to calculating E[y $\left.\mid \mathrm{x}\right]$ at the means of the other variables, first when $\mathrm{PR}=1$ and second when $\mathrm{PR}=0$, and then taking the difference between the two. We thank Denise Young for providing us with the SHAZAM program to make this calculation.

${ }^{46}$ We have run regression 1 in Table 9 without a PR dummy, but with a 'small country' dummy. The results are similar. We postpone sorting out these two effects until a future paper.

${ }^{47}$ This paragraph is based on Kossmann (1978).
} 
hit by the long depression from 1873 to 1895 and there was social unrest. The major political aim of the trade union movement, and its ally, the Parti ouvrier belge (POB) formed in 1885, was universal franchise in order to promote greater social protection. Up until the granting of the right to vote, the dominant Catholic party remained indifferent to these demands. In 1893 men received the right to vote. The Catholic majority remained entrenched, but the opposition was able to push trough proportional representation in 1899. Thereafter, social reforms multiplied: introduction of old age pensions in1900, accident compensation in 1903, and unemployment insurance, 1907. Militancy waned and, after the POB formed a coalition with the radical liberals, workers began to actively participate in setting the policy agenda. Throughout this period, workers' movements and their political partners supported free trade, but only with PR were workers able to use their newly gained voting rights to get some of their demands for social protection met.

\section{Conclusion: more lessons from history}

The decades before 1913 saw the expansion of international trade and the rise of social protection. This was not a mere coincidence. With globalization, European workers faced increasing uncertainty and their conditions of work suffered. They demanded social protection and, in response, national authorities introduced labour compacts. Even in the absence of generous social entitlements, the labour compact provided workers with insurance because it compressed wage structures. We have found that the labour compact was most extensive where the exposure to trade was greater. Our results are robust. They hold for different sub-sets of our sample and for different measures of the labour compact. Moreover, we find the same association between trade and social protection using Lindert's estimates of social spending.

Holding trade shares constant, the proportion of adult male voters in the population was a significant determinant of the extent of the labour compact. But the nature of political institutions may have mattered more. Proportional representation appears to have been a vehicle for workers to exchange their support of trade for concessions from the state. The upshot is that democracy was good for growth because it was good for trade and good for workers. As for its components, the labour compact varied across Europe. Larger states with sizeable domestic markets tended to use labour market and factory regulations; countries with more exposure to 
international markets, many of whom were small, opted for social insurance type programs. Many of these findings are echoed in research on current trends in European economic integration (Ehrenberg 1994, Jacoby 1995). Overall, however, it is difficult to separate the influence of PR and small states in the formation of the labour compact. This is a subject for future research.

The received view is that national authorities in Europe before 1913, faced by falling world grain prices, had two choices: markets or the protection of agriculture. We have argued that there was an alternative. Economic integration involved dislocation and was costly to all types of workers, in agriculture as in industry. The labour compact was an alternative to tariffs because it provided workers with protection against external risk. Thus, in countries with extensive labour compacts, like Belgium and Denmark, industrial workers were enthusiastic supporters of free trade. Herein lies another lesson of history. Globalization expanded in the period before 1913 because it was associated with increased worker protection. As today, free trade was less well received where workers were forced to go it alone. 


\section{Appendix}

AREA: Boundaries and area in millions of square kms. Values for 1870, 1900 and 1910. Source: Foreman-Peck and Lains (2000).

ETHNIC: Average value of five different indexes of ethnolinguistic fractionalization. Its value ranges from 0 to 1 . Components are: (1) index of ethnolinguistic fractionalization which measures the probability that two randomly individuals in a given country are not a member of the same linguistic group; (2) probability that two randomly selected individuals do not speak the same language; (3) probability that two randomly selected individuals speaking different languages; (4) percent of population not speaking the official language; (5) percent of population not speaking the most widely used language. All values for 1960. Source La Porta, et al. (1999).

GDP: GDP per capita in 1990 Geary-Khamis Dollars. Values for 1870, 1900 and 1913. Source: Madison (1995).

GDP\%: Average annual rate of growth of GDP per capita in the period prior to the year selected. For 1870, average annual growth for the period 1850-1870; for 1900, average annual growth for 1890-1899; for 1913, 1903-1912. Source: Madison (1995).

NONAG: Share of labour force in non-agricultural sectors. Values for 1870, 1900 and 1913. Source: Lindert (data sheet), Mitchell (1980).

POP: Population. Values for 1870, 1900 and closest date to 1913. Source: Mitchell (1980).

PR: A binary variable $(1=$ proportional representation; $0=$ none $)$. All countries that introduced PR up until 1917. Belgium 1899; Denmark, 1866; Finland, 1906; Netherlands, 1917; Sweden, 1907. Source: Mackie and Rose (1974).

TARIFF: Average (manufacturing and agriculture) tariff rates. Values for 1870, 1900 and 1910. Source: Foreman-Peck and Lains (2000).

TRADE: Value of exports and imports as a share of GDP. Values for 1870, 1900 and 1913, unless otherwise indicated. Source: Bairoch (1976), Grassman (1980), Maddison (1995), and Mitchell (1980).

UNION: Percentage of labour force unionized. Values for the closest years to 1870,1900 and 1913. Unreported countries received a value of zero. Source: Crouch (1993).

VOTE: Percentage of male population over 21 years of age having right to vote. Values for the closest years to 1870, 1900 and 1913. Unreported countries received a value of zero. Source: Crouch (1993), Flora (1983). 


\section{REFERENCES:}

Agell, J. (1999). On the Benefits from Rigid Labour Markets: Norms, Market Failures and Social Insurance. Economic Journal 108, pp. F143-F164.

Agell, J. (2000). On the Determinants of Labour Market Institutions: Rent Sharing vs. Social Insurance. CESifo, Working Paper no. 384.

Alcock, A. E. (1971). History of the ILO. New York: Octagon Books.

Alesina, A., Baqir, R., and Easterly, W. (1999). Public Goods and Ethnic Divisions. Quarterly Journal of Economics 114, pp. 1243-84.

Alter, G. (1984). Work and Income in the Family Economy of Belgium. Journal of Interdisciplinary History 15, pp. 255-76.

Ambrosius, G. and Hubbard, W. H. (1989). A Social and Economic History of 20th Century Europe. Cambridge: Harvard University Press.

Association Internationale pour la lutte contre le chômage. (1913). State Unemployment Insurance in Various Countries. Reports to the 1re Assemblée Générale. Geneva.

Bairoch, P. (1976). Commerce extérieur et développement économique de l'Europe au XIXe siècle. Paris: Mouton.

Bairoch, P. (1989). European Trade Policy, 1815-1914. In P. Mathias and S. Pollard (eds.), Cambridge Economic History of Europe, Volume VIII, The Industrial Economies: The Development of Economic and Social Policies. Cambridge: Cambridge University Press.

Bellom, M. (1897). État actuel de la question des accidents du travail dans les différents pays. Congrès International des Accidents du Travail: Rapports. Brussels.

Blaustein, S. J. (1993). Unemployment Insurance in the United States: The First Half Century. Kalamazoo: Upjohn Institute.

Blaustein, S. J. and Craig, I. (1977). An International Review of Unemployment Insurance Schemes. Kalamazoo: Upjohn Institute.

Brooke, E. (1898). Factory Laws of European Countries. London.

Cameron, D. R. (1978). The Expansion of the Public Economy: A Comparative Analysis. American Political Science Review 72, pp. 1243-61.

Canning, K. (1996). Languages of Labor and Gender: Female Factory Work in Germany, 1850-1914. Ithaca: Cornell University Press. 
Clark, H. (1941). Swedish Unemployment Policy-1914 to 1940. Washington: American Council on Public Affairs.

Clemens, M. and Williamson, J. G. (2001). A Tariff-Growth Paradox? Protection's Impact the World Around 1875-1997. National Bureau of Economic Research, Working Paper no. 8459.

Commons, J. R. and J, B. Andrew. (1936). The Principles of Labor Legislation. Fourth edition. New York: Harper and Brothers.

Crafts, N. F. R. (1997). The Human Development Index and Changes in Standards of Living: Some Historical Comparisons. European Review of Economic History 1, pp. 299-322.

Crouch, C. (1993). Industrial Relations and European State Traditions. Oxford: Clarendon.

Delevingne, M. (1934). The Pre-War History of International Labor Legislation. In J. T. Shotwell (ed.), The Origins of the International Labor Organization, Vol. 1. New York: Columbia University Press.

Droz, N. (1889). État de la question des accidents du travail. Congrès International des Accidents du Travail, Rapports, vol. 1. Paris.

Ehrenberg, R. G. (1994). Labor Markets and Integrating National Economies. Washington: Brookings Institution.

Epstein, A. (1933). Insecurity: A Challenge to America: A Study of Social Insurance in the United States and Abroad. New York: Harrison Smith.

Flora, P. (1983). State, Economy and Society in Western Europe, 1815-1975. Frankfurt: Campus Verlag.

Follows, J. W. (1951). Antecedents of the International Labour Organization. Oxford: Oxford University Press.

Foreman-Peck, J. and Lains, P. (2000). European Economic Development: The Core and the Southern Periphery, 1870-1910. In S. Pamuk and J. G. Williamson (eds.), The Mediterranean Response to Globalization before 1950. London: Routledge.

Fraser, D. (1984). The Evolution of the British Welfare State. Second edition. London: Macmillan.

Gourevitch, P. (1986). Politics in Hard Times: Comparative Responses to International Economic Crises. Itahca: Cornell University Press.

Grassman, S. (1980). Long-Trends in Openness of National Economies. Oxford Economic Papers 32, pp. 123-33.

Greene, W. (2000). Econometric Analysis. New York: MacMillan. 
Hatton, T. J. and Williamson, J. G. (1998). The Age of Migration: Causes and Economic Impact. New York: Oxford University Press.

Heikkinen, S. (1997). Labour and the Market: Workers, Wages and Living Standards in Finland, 1850-1913. Helsinki: Finish Society of Sciences and Letters.

Hentschel, V. (1989). German Economic and Social Policy, 1815-1939. In P. Mathias and S. Pollard (eds.), Cambridge Economic History of Europe, Volume VIII, The Industrial Economies: The Development of Economic and Social Policies. Cambridge: Cambridge University Press.

Hicks, J. R. (1963). A Theory of Wages. New York: St. Martin's Press.

Huberman, M. and Lewchuk, W. (1998). Glory Days? Work Hours, Labour Market Regulations and Convergence in Late Nineteenth Century Europe. In G. Federico et al. (eds.), Integration of Commodity Markets in History. Proceedings of the Twelfth International Economic History Congress. Madrid: Fundacion Fomento de la Historia Economica

Industrial Relations Counselors. (1934). An Historical Basis for Unemployment Insurance. Minneapolis: University of Minnesota Press.

International Association for Labour Legislation (IALL). (1907). Report of the 4th General Meeting of the Committee of the IALL. Geneva, September 26-29, 1906. London.

IALL. (1911). First Comparative Report on the Administration of Labour Laws: Inspection in Europe. London.

International Labour Office (ILO). (1923). Factory Inspection: Historical Development and Present Organization in Certain Countries. Geneva: ILO.

ILO. (1939). The Organisation of Labour Inspection in Industrial and Commercial Undertakings. Geneva: ILO.

Jacoby, S. (ed.) (1995). The Workers of Nations: Industrial Relations in a Global Economy. New York: Oxford University Press.

Johnston, G. A. (1970). The ILO. London: Europa.

Katzenstein, P. (1985). Small States in World Markets: Industrial Policy in Europe. Ithaca: Cornell University Press.

Kemp, T. (1989). Economic and Social Policy in France. In P. Mathias and S. Pollard (eds.), Cambridge Economic History of Europe, Volume VIII, The Industrial Economies: The Development of Economic and Social Policies. Cambridge: Cambridge University Press.

Kenwood, A. G. and Lougheed, A. L. (1983). The Growth of the International Economy, 18201980. London: George Allen \& Unwin. 
Kindleberger. C. P. (1951). Group Behavior and International Trade. Journal of Political Economy 59, pp. 30-46.

Kossmann, E. H. (1978). The Low Countries, 1780-1940. Oxford: Clarendon Press.

Krueger, A. B. (2000). From Bismarck to Maastricht: The March to European Union and the Labor Compact. National Bureau of Economic Research, Working Paper no. 7456.

La Porta, R., and Lopez-de-Silanes, F., Shleifer, A., and Vishny, R. (1999). The Quality of Government. Journal of Law, Economics, \& Organization 15, pp. 222-82.

Leboutte, R., Puissant, J., and Scuto, D. (1998). Un siècle d'histoire industrielle (1873-1973): Belgique, Luxembourg, Pays-Bas: industrialisations et sociétés. Paris: SEDES.

Lindert, P. H. (1994). The Rise of Social Spending. Explorations in Economic History 31, pp. $1-38$.

Lindert, P. H. (1998). Poor Relief before the Welfare State: Britain versus the Continent, 17801880. European Review of Economic History 2, pp. 101-40.

Lindert, P. H. and Williamson, J. G. (2001). Does Globalization Make the World more Unequal? National Bureau of Economic Research, Working Paper no. 8228.

Low, M. (1907). A Short History of Labor Legislation in Great Britain. Bulletin of the Bureau of Labor, Washington, no. 70, pp. 534-61.

Machlan, L. (1985). Workers' Insurance Versus Protection of the Workers: State Social Policy in Imperial Germany. In P. Weindling (ed.), Social History of Occupational Health. London: Croom Helm.

Mackie, T. T. and Rose, R. (1974). The International Almanac of Electoral History. London: MacMillan.

Maddison, A. (1995). Monitoring the World Economy, 1820-1992. Paris: Organization for Economic Cooperation and Development.

Mansfield, E. D. and Busch, M. L. (1995). The Political Economy of Nontariff Barriers: A Cross-National Analysis. International Organization 49, pp. 723-49.

Mitchell, B. R. (1980). European Historical Statistics, 1750-1975. Second edition. New York: Facts on File.

Murray, J. E. (2000). Government Insurance, Worker Health, and Labor Supply in turn-of the century Europe. University of Toledo, unpublished manuscript. 
Ogus, A. I. (1982). Great Britain. In P. A. Kohler and H. Zacher (eds.), The Evolution of Social Insurance, 1881-1981. London: St. Martin's Press.

O'Rourke, K. H. (2000). Tariffs and Growth in the Late $19^{\text {th }}$ Century. Economic Journal 110, pp. $456-83$.

O'Rourke, K. H. (2001). Globalization and Inequality: Historical Trends. National Bureau of Economic Research, Working Paper no. 8339.

O'Rourke, K. H., and Williamson, J. G. (1999). Globalization and History: The Evolution of a Nineteenth-Century Atlantic Economy. Cambridge: MIT Press.

Rimlinger, G. V. (1971). Welfare Policy and Industrialization in Europe, America and Russia. New York: Wiley.

Rist, C. (1898). La réglementation légale de la journée de travail de l'ouvrier adulte. Paris: Larose.

Rodrik, D. (1997). Has Globalization Gone Too Far? Washington: Institute for International Economics.

Rodrik, D. (1998). Why Do More Open Economies Have Bigger Governments? Journal of Political Economy 106, pp. 997-1033.

Rogowski, R. (1987). Trade and the Variety of Democratic Institutions. Industrial Organization 41, pp. 203-23.

Rogowski, R. (1989). Commerce and Coalitions: How Trade Affects Domestic Political Alignments. Princeton: Princeton University Press.

Rolin-Jaequemyns, M. G. (1890). La conférence de Berlin sur la législation du travail et le socialisme dans le droit international. Revue de droit international et de législation comparée 22, pp. 3-27.

Rosoli, G. (1985). Italian Migration to European Countries from Political Unification to World War One. In D. Hoerder (ed.), Labor Migration in the Atlantic Economies. Westport, Conn.: Greenwood Press, 1985.

Rustow, D. A. (1955). The Politics of Compromise: a Study of the Parties and Government in Sweden. Princeton: Princeton: University Press.

Scholliers, P. (1991). Family Income, Needs and Mother's Wages: A Critical Survey of Working Class Budget Inquiries in Belgium, 1853-1929. In T. Pierenkemperer (ed.), Zur Ökonomik des privaten Haushalts. Frankfort: Verlag. 
Schremmer, D. E. (1989). Taxation and Public Finance: Britain, France and Germany. In P. Mathias and S. Pollard (eds.), Cambridge Economic History of Europe, Volume VIII, The Industrial Economies: The Development of Economic and Social Policies. Cambridge: Cambridge University Press.

Shotwell, J. T. (ed.) (1934). Origins of the ILO, Vol. 1. New York: Columbia University Press.

Sinn, H.-W. (1995). Social Insurance, Incentives and Risk Taking. National Bureau of Economic Research, Working Paper no. 5335.

Smits, J. P. and van Zanden. J. L. (1998). Industrialization and Income Inequality in the Netherlands 1800-1914. In L. Borodkin and P. Lindert, (eds.), Trends in Income Inequality during Industrialization. Proceedings of the Twelfth International Economic History Congress. Madrid: Fundacion Fomento de la Historia Economica.

Taylor, A. M. and Williamson, J. G. (1997). Convergence in the Age of Mass Migration. European Review of Economic History 1, pp. 27-63.

Tegle, S. (1982). Den Ordinarie Veckoarsbetstiden i Sverige, 1860-1980: En översikt. Unpublished manuscript, University of Lund.

Troclet, L. E. (1952). Législation sociale internationale. Les Cahiers de l'Institute de Sociologie Solvay, Cahier \#4. Brussels.

Twarog, S. (1997). Heights and Living Standards in Germany, 1850-1939: The Case of Wurttemberg. In R. H. Steckel and R. Floud (eds.), Health and Welfare during Industrialization. Chicago: University of Chicago Press.

United Kingdom. Parliamentary Papers (PP). (1870). Reports from Her Majesty's Diplomatic and Consular Agents, vol. LXVI.

UK. PP. (1871). Reports from Her Majesty's Diplomatic and Consular Agents, vol. LXVIII.

UK. PP. (1872). Reports from Her Majesty's Diplomatic and Consular Agents, vol. LXII.

UK. PP. (1893-94). Commission on Labour, Foreign Reports, vol. XXXIX.

UK. PP. (1899). First Annual Abstract of Foreign Labour Statistics, vol. XCII.

UK. PP. (1901). Second Annual Abstract of Foreign Labour Statistics, vol. LXXIII.

UK. PP. (1905). International Conference on Labour, vol. LXXIII.

UK. PP. (1906). Third Annual Abstract of Foreign Labour Statistics, vol. CXIII.

UK. UK Commercial (1890). Further Correspondence Respecting the International Labour Conference at Berlin, C-6042, no. 16, pp. 1-183. 
United States. Department of Labor. (1900). Fifteenth Annual Report of the Commissioner of Labor: Wages in Commercial Countries. Washington.

US. Department of Labor. (1911). 24th Annual Report of the Commissioner of Labour. (1909). Workmen's Insurance and Compensation Systems in Europe. Washington.

US. Department of Labor. (1914). Workmen's Compensation Laws of the United States and Foreign Countries. Bulletin of the United States Bureau of Labor Statistics, Department of Labor, no. 126.

Villard. H. G. (1913). Workmen's Accident Compensation and Insurance in Belgium, Norway, Sweden, Denmark and Italy. New York.

Weir, D. R. (1997). Economic Welfare and Physical Well-Being in France, 1750-1990. In R. H. Steckel and R. Floud (eds.), Health and Welfare during Industrialization. Chicago: University of Chicago Press.

Williamson, J. G. (1995). The Evolution of Global Labor Markets since 1830: Background Evidence and Hypotheses. Explorations in Economic History 32, pp. 141-96.

Williamson, J. G. (1996). Globalization, Convergence, and History. Journal of Economic History 56, pp. 277-306.

Williamson, J. G. (1997). Globalization and Inequality, Past and Present. World Bank Research Observer 12, pp. 117-35.

Williamson, J. G. (2000). Land, Labor and Globalization in the Pre-industrial Third World. National Bureau of economic Research, Working Paper, no. 7784.

Wolfenden, H. H. (1934). Unemployment Funds: A Survey and Proposal. Toronto: MacMillan, 1934

Wood, A. (1995). How Trade Hurt Unskilled Workers. Journal of Economic Literature 9, pp. 57-81.

Wooldridge, J. M. (2000). Introductory Econometrics: A Modern Approach. South-Western College Publishing.

Zollner, D. (1982). Germany. In P. A. Kohler. and H. Zacher (eds.), The Evolution of Social Insurance: 1881-1981. London: St. Martin's Press.

Publishing. 
Table 1: Imports and Exports as a Share of GDP

\begin{tabular}{|l|l|l|l|}
\hline & $\mathbf{1 8 7 0}$ & $\mathbf{1 9 0 0}$ & $\mathbf{1 9 1 3}$ \\
\hline Austria-Hungary & $0.13(15)$ & $0.12(14)$ & $0.16(15)$ \\
\hline Belgium & $0.63(1)$ & $0.73(1)$ & $0.76(1)$ \\
\hline Bulgaria & $0.14(14)$ & $0.18(12)$ & $0.17(14)$ \\
\hline Denmark & $0.50(3)$ & $0.47(5)$ & $0.61(2)$ \\
\hline Finland & $0.22(10)$ & $0.29(9)$ & $0.27(11)$ \\
\hline France & $0.24(9)$ & $0.28(10)$ & $0.31(9)$ \\
\hline Germany & $0.37(6)$ & $0.31(8)$ & $0.37(8)$ \\
\hline Italy & $0.18(11)$ & $0.20(11)$ & $0.29(10)$ \\
\hline Netherlands & $0.54(2)$ & $0.60(2)$ & $0.54(3)$ \\
\hline Norway & $0.34(7)$ & $0.44(6)$ & $0.51(4)$ \\
\hline Portugal & $0.13(15)$ & $0.14(13)$ & $0.13(16)$ \\
\hline Russia & $0.15(13)$ & $0.07(16)$ & $0.18(13)$ \\
\hline Spain & $0.16(12)$ & $0.11(15)$ & $0.20(12)$ \\
\hline Sweden & $0.32(8)$ & $0.39(7)$ & $0.42(7)$ \\
\hline Switzerland & $0.47(4)$ & $0.52(3)$ & $0.47(5)$ \\
\hline United Kingdom & $0.47(4)$ & $0.50(4)$ & $0.48(6)$ \\
\hline & & & 0.37 \\
\hline European average & 0.31 & 0.33 & \\
\hline
\end{tabular}

Notes: Rankings in parentheses

Sources: see Appendix. 
Table 2: Labour Market Regulation in Europe until 1913

\begin{tabular}{|c|c|c|c|c|c|c|c|}
\hline & $\begin{array}{l}\text { Minimum } \\
\text { age } 12\end{array}$ & $\begin{array}{l}\text { Ten hour } \\
\text { working day } \\
\text { youths }\end{array}$ & $\begin{array}{l}\text { Night work } \\
\text { children } \\
\text { prohibited }\end{array}$ & $\begin{array}{l}\text { Night work } \\
\text { women } \\
\text { prohibited }\end{array}$ & $\begin{array}{l}\text { Eleven hour } \\
\text { working day } \\
\text { women }\end{array}$ & $\begin{array}{l}\text { Introduction } \\
\text { of factory } \\
\text { inspection }\end{array}$ & $\begin{array}{l}\text { Introduction } \\
\text { of first } \\
\text { factory acts }\end{array}$ \\
\hline Austria & 1885 & 1843 & 1842 & 1895 & 1895 & 1883 & 1787 \\
\hline Belgium & 1889 & $*$ & 1889 & $1909 \mathrm{e}$ & $*$ & 1889 & 1889 \\
\hline Bulgaria & 1905 & $*$ & - & $1909 \mathrm{e}$ & 1913 & 1905 & - \\
\hline Denmark & 1901 & 1901 & 1891 & $*$ & $*$ & 1873 & 1873 \\
\hline Finland & 1889 & $*$ & - & $*$ & $*$ & 1889 & - \\
\hline France & 1871 & 1892 & 1892 & 1892 & 1892 & 1874 & 1841 \\
\hline Germany & 1853 & 1839 & 1839 & 1891 & 1891 & 1853 & 1839 \\
\hline Hungary & 1840 & 1893 & 1884 & $1909 \mathrm{e}$ & $*$ & 1893 & 1840 \\
\hline Italy & 1907 & $*$ & 1902 & 1907 & $*$ & 1906 & 1886 \\
\hline Netherlands & 1889 & 1913 & 1889 & 1889 & 1889 & 1895 & 1874 \\
\hline Norway & 1892 & 1892 & 1892 & $1909 \mathrm{e}$ & $*$ & 1892 & 1892 \\
\hline Portugal & $*$ & 1891 & $*$ & $1909 \mathrm{e}$ & $*$ & 1893 & 1891 \\
\hline Russia & 1907 & $*$ & $*$ & 1905 & $*$ & 1882 & 1882 \\
\hline Spain & $*$ & $*$ & 1900 & $1909 \mathrm{e}$ & $*$ & 1907 & 1873 \\
\hline Sweden & 1881 & 1890 & 1892 & $1909 \mathrm{e}$ & $*$ & 1889 & 1881 \\
\hline Switzerland & 1833 & $*$ & 1837 & 1894 & 1894 & 1877 & 1877 \\
\hline $\begin{array}{l}\text { United } \\
\text { Kingdom }\end{array}$ & \begin{tabular}{|l}
1899 \\
\end{tabular} & $*$ & 1833 & 1844 & 1850 & 1833 & 1833 \\
\hline
\end{tabular}

Notes: * indicates did not enact such a regulation

- indicates information not available

$\mathrm{e}$ indicates mid-point estimate

Sources: see text. 
Table 3: Social Insurance in Europe until 1913

\begin{tabular}{|c|c|c|c|c|}
\hline & \begin{tabular}{|l|} 
Accident \\
compensation
\end{tabular} & $\begin{array}{l}\text { Unemployment } \\
\text { insurance }\end{array}$ & Sickness insurance & Old age insurance \\
\hline Austria & 1887 & $*$ & 1888 & $*$ \\
\hline Belgium & 1903 & $1907 / 1920(\mathrm{~V})$ & 1894 & $1900(\mathrm{~V})$ \\
\hline Bulgaria & 1908 & $*$ & $*$ & $*$ \\
\hline Denmark & 1898 & 1907(V) & $1892(\mathrm{~V})$ & 1891 \\
\hline Finland & 1893 & $*$ & $*$ & $*$ \\
\hline France & 1898 & $1905(\mathrm{~V})$ & $1898(\mathrm{~V})$ & $1900(\mathrm{~V})$ \\
\hline Germany & 1884 & $*$ & 1883 & 1889 \\
\hline Hungary & 1907 & $*$ & 1907 & $*$ \\
\hline Italy & 1898 & $*$ & $1886(\mathrm{~V})$ & $1898(\mathrm{~V})$ \\
\hline Netherlands & 1901 & $*$ & 1913 & 1913 \\
\hline Norway & 1894 & $1906(\mathrm{~V})$ & 1909 & $*$ \\
\hline Portugal & 1913 & $*$ & $*$ & $*$ \\
\hline Russia & - & $*$ & - & $*$ \\
\hline Spain & 1900 & $*$ & $*$ & $*$ \\
\hline Sweden & 1901 & $*$ & 1891(V) & 1913 \\
\hline Switzerland & 1911 & $*$ & 1911(V) & $*$ \\
\hline $\begin{array}{l}\text { United } \\
\text { Kingdom }\end{array}$ & \begin{tabular}{|l}
1897 \\
\end{tabular} & 1911 & 1911 & 1908 \\
\hline
\end{tabular}

Notes: * indicates did not enact such a regulation

- indicates information not available

$\mathrm{V}$ stands for a voluntary scheme

Sources: see text. 
Table 4: Labour Compact Index

\begin{tabular}{|c|c|c|c|c|c|c|c|c|c|}
\hline & 1830 & 1840 & 1850 & 1860 & 1870 & 1880 & 1890 & 1900 & 1913 \\
\hline Austria & $0.091 \quad(1)$ & $0.091 \quad(5)$ & $0.202 \quad(3)$ & $0.217 \quad(3)$ & $0.217 \quad(3)$ & $0.217 \quad(6)$ & $0.561 \quad(2)$ & $0.720 \quad(2)$ & 0.811 (4) \\
\hline Belgium & 0 & 0 & 0 & 0 & 0 & 0 & $0.338 \quad(6)$ & $0.383 \quad(10)$ & $0.731 \quad(7)$ \\
\hline Bulgaria & 0 & 0 & 0 & 0 & 0 & 0 & 0 & 0 & $0.624 \quad(12)$ \\
\hline Denmark & 0 & 0 & 0 & 0 & 0 & $0.235 \quad(5)$ & $0.235 \quad(10)$ & $0.553 \quad(6)$ & $0.667 \quad(10)$ \\
\hline Finland & 0 & 0 & 0 & 0 & 0 & 0 & $0.242 \quad(9)$ & 0.333 & $0.447 \quad(17)$ \\
\hline France & 0 & 0 & $0.159 \quad(4)$ & 0.159 (4) & $0.159 \quad(4)$ & 0.311 & $0.311 \quad(3)$ & $0.674 \quad(3)$ & $0.833 \quad(2)$ \\
\hline Germany & 0 & $0.224 \quad(2)$ & $0.224 \quad(2)$ & $0.361 \quad(2)$ & $0.361 \quad(2)$ & $0.406 \quad(3)$ & $0.633 \quad(1)$ & $0.808 \quad(1)$ & $0.830 \quad(3)$ \\
\hline Hungary & 0 & $0.152 \quad(3)$ & $0.152 \quad(5)$ & $0.121 \quad(5)$ & $0.121 \quad(5)$ & $0.121 \quad(8)$ & $0.194 \quad(11)$ & 0.330 & $0.603 \quad(13)$ \\
\hline Italy & 0 & 0 & 0 & 0 & 0 & 0 & 0.188 (12) & 0.324 & $0.658 \quad(11)$ \\
\hline Netherlands & 0 & 0 & 0 & 0 & 0 & $0.091 \quad(9)$ & $0.417 \quad(5)$ & $0.463 \quad(5)$ & $0.739 \quad(6)$ \\
\hline Norway & 0 & 0 & 0 & 0 & 0 & 0 & 0 & $0.470 \quad(7)$ & $0.712 \quad(9)$ \\
\hline Portugal & 0 & 0 & 0 & 0 & 0 & 0 & 0 & $0.294 \quad(15)$ & $0.476 \quad(16)$ \\
\hline Russia & 0 & 0 & 0 & 0 & 0 & 0 & 0.182 & 0.311 & $0.540 \quad(14)$ \\
\hline Spain & 0 & 0 & 0 & 0 & 0 & $0.155 \quad(7)$ & 0.155 & 0.155 (16) & $0.483 \quad(15)$ \\
\hline Sweden & 0 & 0 & 0 & 0 & 0 & 0 & $0.288 \quad(8)$ & $0.424 \quad(9)$ & $0.758 \quad(5)$ \\
\hline Switzerland & $0.018 \quad(2)$ & 0.133 (4) & $0.133 \quad(6)$ & $0.144 \quad(6)$ & $0.114 \quad(6)$ & $0.443 \quad(2)$ & $0.443 \quad(4)$ & $0.625 \quad(5)$ & $0.716 \quad(8)$ \\
\hline United Kingdom & 0 & $0.311 \quad(1)$ & $0.483 \quad(1)$ & $0.483 \quad(1)$ & $0.483 \quad(1)$ & 0.559 & $0.559 \quad(3)$ & $0.634 \quad(4)$ & $0.907 \quad(1)$ \\
\hline Max-min & 0.091 & 0.311 & 0.483 & 0.483 & 0.483 & 0.559 & 0.633 & 0.808 & 0.460 \\
\hline St. dev. & 0.022 & 0.096 & 0.133 & 0.146 & 0.146 & 0.183 & 0.195 & 0.210 & 0.135 \\
\hline Mean & 0.006 & 0.053 & 0.080 & 0.086 & 0.086 & 0.149 & 0.279 & 0.441 & 0.678 \\
\hline Coef. var & 366.7 & 178.9 & 167.0 & 170.1 & 170.1 & 123.1 & 69.99 & 47.67 & 19.94 \\
\hline Interquartile & 0 & 0.046 & 0.076 & 0.061 & 0.061 & 0.118 & 0.118 & 0.151 & 0.078 \\
\hline
\end{tabular}

Notes: Rankings in parentheses.

Sources: See text. 
Table 5: Indexes of Labour Market Regulation and Social Insurance

\begin{tabular}{|c|c|c|c|c|c|c|}
\hline & \multicolumn{3}{|c|}{ Market regulation index } & \multicolumn{3}{|c|}{ Social insurance index } \\
\hline & 1870 & 1900 & 1913 & 1870 & 1900 & 1913 \\
\hline Austria & $.340(3)$ & $.846(3)$ & $.846(5)$ & 0 & $.500(3)$ & $.750(2)$ \\
\hline Belgium & 0 & $.531(9)$ & $.721(11)$ & 0 & $.125(9)$ & $.750(2)$ \\
\hline Bulgaria & 0 & 0 & $.838(6)$ & 0 & 0 & $.250(13)$ \\
\hline Denmark & 0 & $.512(11)$ & $.619(14)$ & 0 & $.625(2)$ & $.750(2)$ \\
\hline Finland & 0 & $.381(14)$ & $.560(17)$ & 0 & $.250(6)$ & $.250(13)$ \\
\hline France & $.250(4)$ & $.845(4)$ & $.881(2)$ & 0 & $.375(5)$ & $.750(2)$ \\
\hline Germany & $.567(2)$ & $.840(5)$ & $.876(3)$ & 0 & $.750(1)$ & $.750(2)$ \\
\hline Hungary & $.190(5)$ & $.519(10)$ & $.662(13)$ & 0 & 0 & $.500(10)$ \\
\hline Italy & 0 & $.224(16)$ & $.749(8)$ & 0 & $.500(3)$ & $.500(10)$ \\
\hline Netherlands & 0 & $.656(6)$ & $.733(10)$ & 0 & $.125(9)$ & $.750(2)$ \\
\hline Norway & 0 & $.595(7)$ & $.738(9)$ & 0 & $.250(6)$ & $.750(2)$ \\
\hline Portugal & 0 & $.462(13)$ & $.605(16)$ & 0 & 0 & $.250(13)$ \\
\hline Russia & 0 & $.488(12)$ & $.720(12)$ & 0 & 0 & $.125(17)$ \\
\hline Spain & 0 & $.244(15)$ & $.615(15)$ & 0 & 0 & $.250(13)$ \\
\hline Sweden & 0 & $.595(7)$ & $.762(7)$ & 0 & $.125(9)$ & $.625(9)$ \\
\hline Switzerland & $.180(6)$ & $.911(1)$ & $.911(1)$ & 0 & $.125(9)$ & $.375(12)$ \\
\hline United Kingdom & $.759(1)$ & $.854(2)$ & $.854(4)$ & 0 & $.250(6)$ & $1(1)$ \\
\hline
\end{tabular}

Notes: Rankings in parentheses.

Sources: See text. 
Table 6: Correlation Coefficients of Dependent and Independent Variables

\begin{tabular}{|c|c|c|c|c|c|c|c|c|c|c|c|c|c|}
\hline & \multicolumn{3}{|c|}{ Labour market compact } & \multicolumn{4}{|c|}{ Macroeconomic variables } & \multicolumn{2}{|c|}{ Size variables } & \multicolumn{4}{|c|}{ Social and political variables } \\
\hline & LCI & LRI & SII & TRADE & TARIFF & GDP & GDP\% & POP & AREA & NONAG & VOTE & UNION & ETHNIC \\
\hline LCI & - & & & & & & & & & & & & \\
\hline LRI & $.947 * *$ & - & & & & & & & & & & & \\
\hline SII & $.842 * *$ & $.641 * *$ & - & & & & & & & & & & \\
\hline TRADE & $.310 *$ & .274 & $.329 *$ & \begin{tabular}{|l}
- \\
\end{tabular} & & & & & & & & & \\
\hline TARIFF & -.125 & -.039 & $-.278 *$ & $-.409 * *$ & - & & & & & & & & \\
\hline GDP & $.705^{* *}$ & $.658 * *$ & $.647 * *$ & $.687 * *$ & $-.450 * *$ & - & & & & & & & \\
\hline GDP\% & $.418^{* *}$ & $.384 * *$ & $.363^{* *}$ & $.308 *$ & $-.304 *$ & -.395 & - & & & & & & \\
\hline POP & .123 & .144 & .009 & $-.435 * *$ & .227 & -.113 & -.143 & \begin{tabular}{|l} 
\\
\end{tabular} & & & & & \\
\hline AREA & -.076 & -.031 & -.172 & $-.441 * *$ & $.362^{*}$ & $-.322 *$ & -.230 & $.901^{* *}$ & - & & & & \\
\hline NONAG & $.501 * *$ & $.453^{* *}$ & $.471^{* *}$ & $.809 * *$ & $-.396 * *$ & $.802^{* *}$ & $.231 *$ & $.303^{*}$ & $-.479 * *$ & - & & & \\
\hline VOTE & $.621 * *$ & $.518 * *$ & $.642 * *$ & $.432 * *$ & -.245 & $.601 * *$ & $.424 * *$ & .062 & -.266 & $.533 * *$ & - & & \\
\hline UNION & $.654 * *$ & $.541 * *$ & $.744 * *$ & $.526 * *$ & $-.352 *$ & $.782 * *$ & .168 & -.065 & -.193 & $.614 * *$ & $.487 * *$ & - & \\
\hline ETHNIC & -.018 & .036 & -.097 & $.391 * *$ & -.043 & $.286^{*}$ & .109 & -.251 & -.215 & $.299 *$ & .022 & .051 & - \\
\hline
\end{tabular}

** significant at the 0.01 level

* significant at the 0.05 level

Sources: see Appendix. 
Table 7: Some Influences on the Labour Compact

\begin{tabular}{|c|c|c|c|c|c|c|c|}
\hline $\begin{array}{l}\text { Dependent } \\
\text { variables }\end{array}$ & $\begin{array}{l}(1) \\
\text { LCI } \\
\text { all } \\
\text { countries }\end{array}$ & $\begin{array}{l}(2) \\
\text { LCI } \\
\text { all } \\
\text { countries }\end{array}$ & $\begin{array}{l}(3) \\
\text { LCI } \\
\text { all } \\
\text { countries }\end{array}$ & $\begin{array}{l}(4) \\
\text { LCI } \\
\text { all } \\
\text { countries }\end{array}$ & $\begin{array}{l}(5) \\
\text { LCI } \\
\text { poor } \\
\text { countries }\end{array}$ & $\begin{array}{l}(6) \\
\text { LINDERT } \\
\text { all } \\
\text { countries }\end{array}$ & $\begin{array}{l}(7) \\
\text { LCI } \\
\text { all } \\
\text { countries }\end{array}$ \\
\hline Constant & $\begin{array}{l}-0.57 \\
(1.69)\end{array}$ & $\begin{array}{l}-0.61 \\
(3.62)\end{array}$ & $\begin{array}{l}-0.68 \\
(4.19)\end{array}$ & $\begin{array}{l}-0.19 \\
(1.85)\end{array}$ & $\begin{array}{l}-0.79 \\
(0.00)\end{array}$ & $\begin{array}{l}2.44 \\
(4.11)\end{array}$ & $\begin{array}{l}-0.75 \\
(3.12)\end{array}$ \\
\hline InTRADE & $\begin{array}{l}0.35^{* *} \\
(3.75) \\
{[0.29]}\end{array}$ & $\begin{array}{l}0.24 * * \\
(5.00) \\
{[0.15]}\end{array}$ & $\begin{array}{l}0.12 * \\
(2.00) \\
{[0.12]}\end{array}$ & $\begin{array}{l}0.16^{*} \\
(2.40) \\
{[0.15]}\end{array}$ & $\begin{array}{c}0.26^{*} \\
(2.41) \\
{[0.14]}\end{array}$ & $\begin{array}{l}0.51 \text { ** } \\
(3.20) \\
{[0.40]}\end{array}$ & \\
\hline InPOP & $\begin{array}{l}0.15^{* *} \\
(3.52)\end{array}$ & $\begin{array}{l}0.10^{* *} \\
(4.71)\end{array}$ & $\begin{array}{l}0.07 * * \\
(3.24)\end{array}$ & & $\begin{array}{l}0.05 \\
(1.78)\end{array}$ & $\begin{array}{l}-0.19 * * \\
(2.82)\end{array}$ & $\begin{array}{c}0.06^{*} \\
(2.69)\end{array}$ \\
\hline InAREA & & & & $\begin{array}{c}0.06^{*} \\
(2.51)\end{array}$ & & & \\
\hline InGDP & & & $\begin{array}{l}0.03 \\
(1.03)\end{array}$ & & & & \\
\hline GDP\% & & & $\begin{array}{l}0.11 \\
(0.39)\end{array}$ & $\begin{array}{l}-0.01 \\
(0.32)\end{array}$ & $\begin{array}{l}-0.01 \\
(0.15)\end{array}$ & $\begin{array}{l}-0.66 \\
(0.54)\end{array}$ & \\
\hline VOTE & & & $\begin{array}{l}002 * * \\
(3.12)\end{array}$ & $\begin{array}{l}-0.003 * * \\
(3.62)\end{array}$ & $\begin{array}{l}0.00 \\
(0.41)\end{array}$ & $\begin{array}{l}0.01 * * \\
(3.16)\end{array}$ & \\
\hline InETHNIC & & & $\begin{array}{l}-0.03 \\
(1.48)\end{array}$ & $\begin{array}{l}-0.02 \\
(0.96)\end{array}$ & & & \\
\hline InTARIFF & & & & & & & $\begin{array}{l}-0.06^{*} \\
(2.29)\end{array}$ \\
\hline T1900 & & $\begin{array}{l}0.42^{* *} \\
(6.23)\end{array}$ & $\begin{array}{l}-0.39 * * \\
(6.44)\end{array}$ & $\begin{array}{l}0.42 * * \\
(6.30)\end{array}$ & $\begin{array}{l}1.04 \\
(0.00)\end{array}$ & $\begin{array}{l}-0.04 \\
(0.24)\end{array}$ & $\begin{array}{l}0.48 * * \\
(5.80)\end{array}$ \\
\hline T1913 & & $\begin{array}{l}0.62 * * \\
(7.40)\end{array}$ & $\begin{array}{l}0.521 * * \\
(6.73)\end{array}$ & $\begin{array}{l}0.58 * * \\
(7.05)\end{array}$ & $\begin{array}{l}1.32 \\
(0.00)\end{array}$ & $\begin{array}{l}-0.04 \\
(0.23)\end{array}$ & $\begin{array}{l}0.71 * * \\
(7.12)\end{array}$ \\
\hline $\mathrm{N}$ & 48 & 48 & 48 & 48 & 24 & 42 & 48 \\
\hline SE of est / " $\mathrm{R}^{2 "}$ & $0.30 / 0.37$ & $0.13 / 0.85$ & $0.11 / 0.89$ & $0.13 / 0.85$ & $0.10 / 0.91$ & $0.34 / 0.56$ & $0.17 / 0.76$ \\
\hline
\end{tabular}

** significant at the 0.01 level

* significant at the 0.05 level

Notes: Tobit regressions. Unnormalized coefficients ( $t$ statistics in parentheses). " $\mathrm{R}$ ", is the squared correlation between observed and expected values of the dependent variable. GDP and TRADE lagged 10 years. GDP is an instrumental variable. Instruments described in text. Means: $\mathrm{LCI}=0.40 ; \mathrm{LRI}=0.46 ; \mathrm{SII}=0.26$; $\mathrm{LINDERT}=0.48 ; \mathrm{TRADE}=0.34$; $\mathrm{POP}=22985 ; \mathrm{AREA}=210.5 ; \mathrm{GDP}=2379 ; \mathrm{GDP} \%=1.02 ; \mathrm{VOTE}=42.38 ; \mathrm{ETHNIC}=1.11 ; \mathrm{TARIFF}=0.10$.

Sources: See Appendix. 
Table 8: Some Influences on Regulation and Insurance

\begin{tabular}{lcccccc}
\hline \hline & \multicolumn{5}{l}{ Social insurance (SII) } \\
Dependent \\
variables
\end{tabular}

** significant at the 0.01 level

* significant at the 0.05 level

Notes: see Table 7. 
Table 9: The Labour Compact and Proportional Representation

\begin{tabular}{|c|c|c|c|c|c|}
\hline Dependent & (1) & (2) & (3) & (4) & (5) \\
\hline & LCI & LCI & LCI & LRI & SII \\
\hline Constant & $\begin{array}{l}-0.86 \\
(2.76)\end{array}$ & $\begin{array}{l}-0.98 \\
(3.17)\end{array}$ & $\begin{array}{l}-0.74 \\
(2.49)\end{array}$ & $\begin{array}{l}-0.80 \\
(2.17)\end{array}$ & $\begin{array}{l}-0.77 \\
(2.07)\end{array}$ \\
\hline InTRADE & $\begin{array}{l}0.21 * \\
(2.42) \\
{[0.19]}\end{array}$ & $\begin{array}{c}0.19 * \\
(2.29) \\
{[0.18]}\end{array}$ & $\begin{array}{l}0.18^{*} \\
(2.12) \\
{[0.17]}\end{array}$ & $\begin{array}{l}0.17 \\
(1.65) \\
{[0.15]}\end{array}$ & $\begin{array}{c}0.16^{*} \\
(2.00) \\
{[0.15]}\end{array}$ \\
\hline InPOP & $\begin{array}{c}0.14^{* *} \\
(3.85)\end{array}$ & $\begin{array}{c}0.14 * * \\
(4.00)\end{array}$ & $\begin{array}{l}0.11^{* *} \\
(3.03)\end{array}$ & $\begin{array}{l}0.13^{* *} \\
(2.83)\end{array}$ & $\begin{array}{l}0.09 \\
(1.97)\end{array}$ \\
\hline GDP\% & $\begin{array}{l}0.09 \\
(1.37)\end{array}$ & $\begin{array}{l}0.10 \\
(1.65)\end{array}$ & $\begin{array}{l}0.06 \\
(0.93)\end{array}$ & $\begin{array}{l}0.08 \\
(0.97)\end{array}$ & $\begin{array}{l}0.05 \\
(0.66)\end{array}$ \\
\hline VOTE & & & $\begin{array}{l}.003 \\
(1.63)\end{array}$ & $\begin{array}{l}.002 \\
(1.05)\end{array}$ & $\begin{array}{l}.003 \\
(1.57)\end{array}$ \\
\hline PR & $\begin{array}{l}0.30 * * \\
(2.74)\end{array}$ & $\begin{array}{l}0.34^{* *} \\
(3.16)\end{array}$ & & & \\
\hline PRVOTE & & & $\begin{array}{c}.003 * \\
(2.03)\end{array}$ & $\begin{array}{l}.003 \\
(1.40)\end{array}$ & $\begin{array}{c}.004 * \\
(2.41)\end{array}$ \\
\hline T1900 & & $\begin{array}{l}0.18^{*} \\
(2.21)\end{array}$ & $\begin{array}{l}0.20 * \\
(2.60)\end{array}$ & & \\
\hline $\mathrm{N}$ & 48 & 48 & 48 & 48 & 48 \\
\hline SE of est /"'R ${ }^{2 \prime \prime}$ & $0.26 / .49$ & $0.25 / .52$ & $.23 / .54$ & $.31 / .41$ & $.29 / .55$ \\
\hline
\end{tabular}

** significant at the 0.01 level

* significant at the 0.05 level

Notes : see Table 7. The mean of $\mathrm{PR}=0.15$ 
Figure 1

Labour Compact

Openness and the Labour Compact in 1913

index, 1913

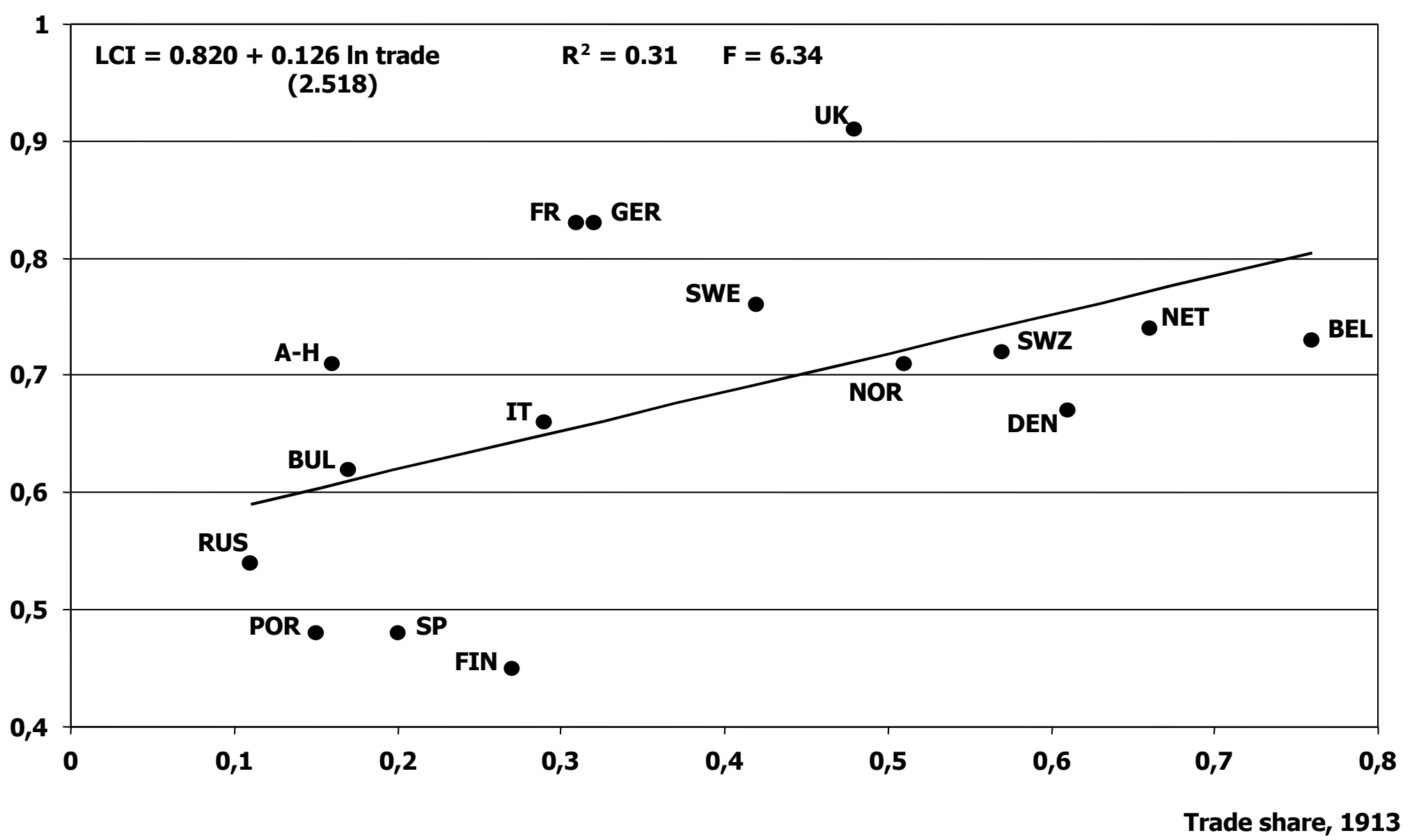




\section{Liste des publications au CIRANO*}

Série Scientifique / Scientific Series (ISSN 1198-8177)

2002s-34 European Economic Integration and the Labour Compact, 1850-1913 / Michael Huberman et Wayne Lewchuk

2002s-33 Which Volatility Model for Option Valuation? / Peter Christoffersen et Kris Jacobs

2002s-32 Production Technology, Information Technology, and Vertical Integration under Asymmetric Information / Gamal Atallah

2002s-31 Dynamique Motivationnelle de l'Épuisement et du Bien-être chez des Enseignants Africains / Manon Levesque, Marc R. Blais, Ursula Hess

2002s-30 Motivation, Comportements Organisationnels Discrétionnaires et Bien-être en Milieu Africain : Quand le Devoir Oblige / Manon Levesque, Marc R. Blais et Ursula Hess

2002s-29 Tax Incentives and Fertility in Canada: Permanent vs. Transitory Effects / Daniel Parent et Ling Wang

2002s-28 The Causal Effect of High School Employment on Educational Attainment in Canada / Daniel Parent

2002s-27 Employer-Supported Training in Canada and Its Impact on Mobility and Wages / Daniel Parent

2002s-26 Restructuring and Economic Performance: The Experience of the Tunisian Economy / Sofiane Ghali and Pierre Mohnen

2002s-25 What Type of Enterprise Forges Close Links With Universities and Government Labs? Evidence From CIS 2 / Pierre Mohnen et Cathy Hoareau

2002s-24 Environmental Performance of Canadian Pulp and Paper Plants : Why Some Do Well and Others Do Not? / Julie Doonan, Paul Lanoie et Benoit Laplante

2002s-23 A Rule-driven Approach for Defining the Behavior of Negotiating Software Agents / Morad Benyoucef, Hakim Alj, Kim Levy et Rudolf K. Keller

2002s-22 Occupational Gender Segregation and Women's Wages in Canada: An Historical Perspective / Nicole M. Fortin et Michael Huberman

2002s-21 Information Content of Volatility Forecasts at Medium-term Horizons / John W. Galbraith et Turgut Kisinbay

2002s-20 Earnings Dispersion, Risk Aversion and Education / Christian Belzil et Jörgen Hansen

2002s-19 Unobserved Ability and the Return to Schooling / Christian Belzil et Jörgen Hansen

2002s-18 Auditing Policies and Information Systems in Principal-Agent Analysis / MarieCécile Fagart et Bernard Sinclair-Desgagné

2002s-17 The Choice of Instruments for Environmental Policy: Liability or Regulation? / Marcel Boyer, Donatella Porrini

2002s-16 Asymmetric Information and Product Differentiation / Marcel Boyer, Philippe Mahenc et Michel Moreaux

\footnotetext{
* Consultez la liste complète des publications du CIRANO et les publications elles-mêmes sur notre site Internet :
} 
2002s-15 Entry Preventing Locations Under Incomplete Information / Marcel Boyer, Philippe Mahenc et Michel Moreaux

2002s-14 On the Relationship Between Financial Status and Investment in Technological Flexibility / Marcel Boyer, Armel Jacques et Michel Moreaux

2002s-13 Modeling the Choice Between Regulation and Liability in Terms of Social Welfare / Marcel Boyer et Donatella Porrini

2002s-12 Observation, Flexibilité et Structures Technologiques des Industries / Marcel Boyer, Armel Jacques et Michel Moreaux

2002s-11 Idiosyncratic Consumption Risk and the Cross-Section of Asset Returns / Kris Jacobs et Kevin Q. Wang

2002s-10 The Demand for the Arts / Louis Lévy-Garboua et Claude Montmarquette

2002s-09 Relative Wealth, Status Seeking, and Catching Up / Ngo Van Long, Koji Shimomura

2002s-08 The Rate of Risk Aversion May Be Lower Than You Think / Kris Jacobs

2002s-07 A Structural Analysis of the Correlated Random Coefficient Wage Regression Model / Christian Belzil et Jörgen Hansen

2002s-06 Information Asymmetry, Insurance, and the Decision to Hospitalize / Åke Blomqvist et Pierre Thomas Léger

2002s-05 Coping with Stressful Decisions: Individual Differences, Appraisals and Choice / Ann-Renée Blais

2002s-04 A New Proof Of The Maximum Principle / Ngo Van Long et Koji Shimomura

2002s-03 Macro Surprises And Short-Term Behaviour In Bond Futures / Eugene Durenard et David Veredas

2002s-02 Financial Asset Returns, Market Timing, and Volatility Dynamics / Peter F. Christoffersen et Francis X. Diebold

2002s-01 An Empirical Analysis of Water Supply Contracts / Serge Garcia et Alban Thomas

2001s-71 A Theoretical Comparison Between Integrated and Realized Volatilities Modeling / Nour Meddahi

2001s-70 An Eigenfunction Approach for Volatility Modeling / Nour Meddahi

2001s-69 Dynamic Prevention in Short Term Insurance Contracts / M. Martin Boyer et Karine Gobert

2001s-68 Serial Cost Sharing in Multidimensional Contexts / Cyril Téjédo et Michel Truchon

2001s-67 Learning from Strike / Fabienne Tournadre et Marie-Claire Villeval

2001s-66 Incentives in Common Agency / Bernard Sinclair-Desgagné

2001s-65 Detecting Mutiple Breaks in Financial Market Volatility Dynamics / Elena Andreou et Eric Ghysels

2001s-64 Real Options, Preemption, and the Dynamics of Industry Investments / Marcel Boyer, Pierre Lasserre, Thomas Mariotti et Michel Moreaux

2001s-63 Dropout, School Performance and Working while in School: An Econometric Model with Heterogeneous Groups / Marcel Dagenais, Claude Montmarquette et Nathalie Viennot-Briot 
2001s-62 Derivatives Do Affect Mutual Funds Returns : How and When? / Charles Cao, Eric Ghysels et Frank Hatheway

2001s-61 Conditional Quantiles of Volatility in Equity Index and Foreign Exchange Data / John W. Galbraith, Serguei Zernov and Victoria Zinde-Walsh

2001s-60 The Public-Private Sector Risk-Sharing in the French Insurance "Cat. Nat. System" / Nathalie de Marcellis-Warin et Erwann Michel-Kerjan

2001s-59 Compensation and Auditing with Correlated Information / M. Martin Boyer et Patrick González

2001s-58 Resistance is Futile: An Essay in Crime and Commitment / M. Martin Boyer

2001s-57 The Unreliability of Output Gap Estimates in Real Time / Athanasios Orphanides et Simon van Norden

2001s-56 Exact Nonparametric Two-Sample Homogeneity Tests for Possibly Discrete Distributions / Jean-Marie Dufour et Abdeljelil Farhat

2001s-55 Les coûts de la réglementation : une revue de la littérature / Robert Gagné, Paul Lanoie, Pierre-Carl Micheud et Michel Patry

2001s-54 Testing for structural Change in the Presence of Auxiliary Models / Eric Ghysels et Alain Guay

2001s-53 Environmental Regulation and Productivity: New Findings on the Porter Hypothesis / Paul Lanoie, Michel Patry et Richard Lajeunesse

2001s-52 The Aftermarket Performance of Initial Public Offerings in Canada / Maher Kooli et Jean-Marc Suret

2001s-51 Capital Structure and Risk Management / Karine Gobert

2001s-50 The Underpricing of Initial Public Offerings: Futher Canadian Evidence / Maher Kooli et Jean-Marc Suret

2001s-49 How Innovative Are Canadian Firms Compared to Some European Firms? A Comparative Look at Innovation Surveys / Pierre Mohnen et Pierre Therrien

2001s-48 A Tale of Two Ports / Ngo Van Long et Kar-yiu Wong

2001s-47 Wage Policy of Firms: An Empirical Investigation / Stéphanie Lluis

2001s-46 Forecasting Some Low-Predictability Time Series Using Diffusion Indices / Marc Brisson, Bryan Campbell et John W. Galbraith

2001s-45 The Importance of the Loss Function in Option Pricing / Peter Christoffersen et Kris Jacobs

2001s-44 Let's Get "Real" about Using Economic Data / Peter Christoffersen, Eric Ghysels et Norman R. Swanson

2001s-43 Fragmentation, Outsourcing and the Service Sector / Ngo Van Long, Ray Riezman et Antoine Soubeyran

2001s-42 Nonlinear Features of Realized FX Volatility / John M. Maheu et Thomas H. McCurdy

2001s-41 Job Satisfaction and Quits: Theory and Evidence from the German Socioeconomic Panel / Louis Lévy-Garboua, Claude Montmarquette et Véronique Simonnet 